\title{
Synthesis and Characterization of Gold(I) Complexes of Dibenzotropylidene-functionalized NHC Ligands (Trop-NHCs)
}

\author{
Marcel Brill, ${ }^{\dagger}$ Alba Collado, ${ }^{\dagger}$ David B. Cordes,${ }^{\dagger}$ Alexandra M. Z. Slawin, ${ }^{\dagger}$ Matthias Vogt, ${ }^{\dagger}$ Hansjörg \\ Grützmacher ${ }^{\dagger}$ and Steven P. Nolan ${ }^{\S \dagger *}$ \\ ${ }^{\dagger}$ EaStCHEM School of Chemistry, University of St Andrews, St Andrews, KY16 9ST, U.K. ${ }^{\S}$ Chemistry Department, Col- \\ lege of Science, King Saud University, Riyadh 11451, Saudi Arabia. ${ }^{\star}$ Department of Chemistry and Applied Biosciences \\ ETH Zürich, Laboratory of Inorganic Chemistry, Wolfgang Pauli Str. 10, 8093 Zürich, Switzerland.
}

KEYWORDS. N-heterocyclic carbene (NHC), functionalized NHC, olefin ligands, buried volume, flexible ligands, gold, bimolecular decomposition.

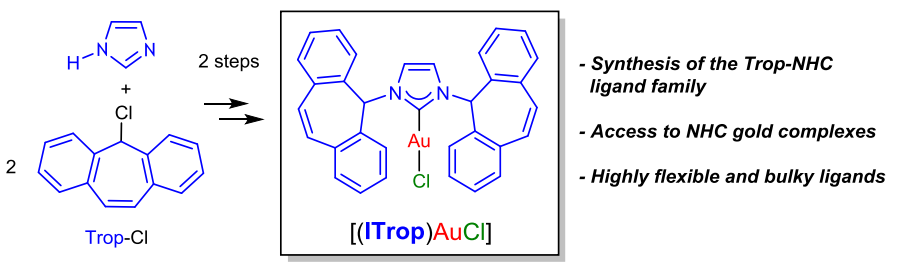

\begin{abstract}
Gold(I) complexes of dibenzotropylidene-functionalized $N$-heterocyclic carbene ligands (Trop-NHCs) have been prepared in order to investigate their structural features and to reveal possible interaction of the olefin-unit with the metal center. The precursor imidazolium chloride salts (R-1) were generated in a single step using $N$-substituted imida-zoles $(\mathrm{R}=\mathrm{H}, \mathrm{Me}, \mathrm{DiPP}$, Ad) and one or two equivalents of Trop- $\mathrm{Cl}$ generating unsymmetrically and symmetrically NHC-olefin hybrids. The structural parameters of the ligands were determined by synthesis and X-ray diffraction analysis of their corresponding gold(I)-chloride complexes revealing highly flexible steric demands of the Trop-unit. Conversion of these complexes with halide abstracting reagents like $\mathrm{AgNTf}_{2}$ and $\mathrm{NaBArF}_{24}$ cleanly gave the neutral, $\mathrm{NTf}_{2}$-coordinated complexes of the type [(NHC)Au(NTf$)$ ] $(\mathbf{R}-3)$ and the cationic bis-NHC-coordinated complexes $\left[(\mathrm{NHC})_{2} \mathrm{Au}\right] \mathrm{BArF}_{24}(\mathbf{R}-\mathbf{4})$, respectively. The Gagosz-type complexes R-3 were further tested in the hydration of diphenylacetylene showing a clear trend in activity depending on the ligands sensitivity to hydrolysis.
\end{abstract}

\section{INTRODUCTION}

The use of $N$-heterocyclic carbenes (NHCs) as ancillary ligands in transition metal catalyzed reactions has become - among many uses in organometallic chemistry ${ }^{1}$ or organocatalysis ${ }^{2}$ - one of their main applications. ${ }^{3,4,5,6}$ Among these, gold(I)-mediated processes have emerged as one of the most active areas of NHCbased catalysis. ${ }^{7}$ The bulky nature and fan-shaped geometry of the most frequently investigated types of ligands ensure sufficient lifetime of the usually in situ generated gold cations of type $[(\mathrm{NHC}) \mathrm{Au}]^{+}$. These represent the postulated active species of many gold-mediated organic transformations.7 Additionally, the strong $\sigma$-donating properties of NHC ligands are believed to play a pivotal role in the stabilization of the low-valent gold center as reported for many other late transition metal catalyzed processes. $4^{\mathrm{b}, 8}$

Numerous labile donors have been investigated to function as stabilizing ligands for isolable, catalytically active gold(I) species of formulae [(L)Au-Y], where $\mathrm{L}$ represents either a phosphine or NHC ligand and Y is a commonly used weakly bound neutral or anionic donor such as $\mathrm{MeCN}$ and other nitrogen based donors, ${ }^{9,}, 10$ $\mathrm{TfO}^{-}$(Trifluoromethylsulfonate) ${ }^{11}$ or $\mathrm{NTf}_{2}$ (Bis(trifluoromethylsulfonyl)imide). ${ }^{12,13}$ A series of complexes in which Y represents an olefin ligand have been reported by Widenhoefer et al., ${ }^{14}$ yet their potential to function as precatalysts has not been fully evaluated to date. $9^{\text {a }}$ We set out to develop a cationic (NHC)gold(I) system, which incorporates an olefin group tethered to an NHC ligand, in order to study possible olefin gold(I) bonding as well as its potential in catalysis.

Grützmacher et al. have studied the coordination chemistry $5 \mathrm{H}$ dibenzo[ $[a, d]$ cyclohepten-5-yl-substituted phosphorus- and nitrogen-based ligands (a.k.a. "dibenzotrop-ylidenyl" or "Trop" ligands). ${ }^{15,16}$ Their studies on coinage metal complexes of Tropsubstituted phosphine ligands ("Tropp's") were able to reveal bonding interactions between the olefin group and $\mathrm{Cu}$ or $\mathrm{Ag}$ centers in certain cases showing tetrahedral $(\mathrm{Cu})$ or strongly distorted trigonal planar and linear geometries around the metal centers $(\mathrm{Ag}) .{ }^{15 \mathrm{~b}}$

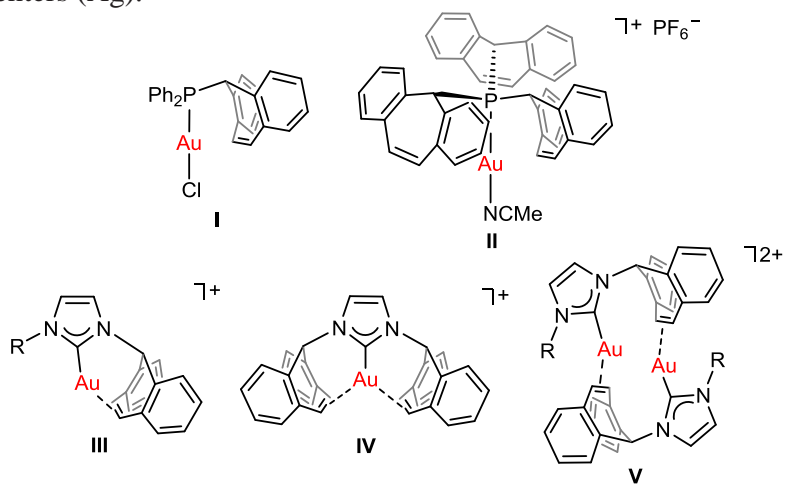

Figure 1. Top: Previously reported Trop-phosphine gold(I) complexes. Bottom: Possible cationic Trop-NHC gold(I) species. 
However, in gold(I) complexes supported by these ligands, no such interaction was observed. Attempts to enforce coordination of the olefin-unit to the gold center in complex $\mathbf{I}$ either by removal of the chloride anion by abstraction with a strong Lewis acid or by replacement with a weakly coordinating ligand were unsuccessful. ${ }^{15 \mathrm{~b}} \mathrm{~A}$ few years after these reports, NMR and X-ray diffraction analysis of the cationic Trop ${ }_{3} \mathrm{P}$-ligated complex II, also did not provide any evidence for an interaction between the more electrophilic gold(I) center and the olefin moiety. ${ }^{17}$

We reasoned that Trop-NHC ligands might represent better candidates for obtaining the first chelated gold(I) complexes of olefin-functionalized ligands. In comparison to the Troppsystems, the fan-shaped geometry of the analogous NHC ligands and the additional nitrogen atom between the Trop-substituent and the donor atom, should accommodate ligands with much larger bite-angles. This should then lead to weaker distortions of the preferred linear geometry or the also feasible trigonal planar geometry in the putative cationic gold(I) complexes III and IV (bearing the symmetrical Trop-NHC ligand "ITrop"), respectively (Figure 1). The dinuclear, dicationic structure $\mathbf{V}$, which represents a common structural motif in the coordination chemistry of coinage metals and bidentate ligands, is also conceivable. This would resemble the bridged analog of the Widenhoefer series of mononuclear NHC olefin complexes. ${ }^{14}$

For the single Trop-NHC gold complex reported so far, which one of us reported more than a decade ago, a similar observation to the Tropp-ligands coordination chemistry was made. ${ }^{18}$ The only accessible complex at the time [(ITrop) $\left.\mathrm{Au}\left(\mathrm{PPh}_{3}\right)\right] \mathrm{Cl}$, did not reveal any interaction of the olefin arm with the gold(I) center. However, this complex proved to be resistant towards substitution of the $\mathrm{PPh}_{3}$ ligand even under harsh conditions. Therefore, neither a complex with a weakly coordinating donor nor a truly naked species of the type [(ITrop)Au $]^{+}$could be investigated initially.

We now report on the synthesis of gold(I) chloride complexes of a series of new unsymmetrical Trop-NHC ligands and of their previously reported symmetrical congener "ITrop", for which we have developed a much simpler synthetic access. These complexes provided the opportunity to study the steric properties of the ligands by X-ray diffraction analysis and their reactivtity towards halide abstracting agents containing weakly or non-coordinating anions with the purpose of investigating possible gold(I) olefin bonding interactions.

\section{RESULTS AND DISCUSSION}

Ligand Synthesis. Due to the high susceptibility of Trop-Cl towards nucleophilic attack, the unsymmetrical ligand precursors R-1 ( $\mathrm{R}=\mathrm{Me}$, DiPP, Ad) were obtained easily by stirring solutions of the corresponding $N$-substituted imidazoles and the electrophile in toluene at room temperature overnight (Scheme 1). ${ }^{19}$ As all compounds required multiple washings with toluene $(\mathrm{R}=\mathrm{Me}$, $\mathrm{DiPP})$ or THF ( $\mathrm{R}=\mathrm{Ad}$ ) in order to be obtained in pure form, the lower yields obtained for compounds DiPP-1 and Ad-1 are attributable to their higher solubility in comparison to Me-1. Since the compounds were hygroscopic and sensitive towards hydrolysis, there were stored under inert atmosphere until further use.

The symmetrical imidazolium salt Trop-1 had previously been synthesized following the most common synthetic strategy for symmetrical NHC ligands: Trop- $\mathrm{NH}_{2}$, which is available from the reaction of Trop-Cl and ammonia at low temperature, can be converted to the corresponding bisimine of glyoxal, which is then cyclized to the imidazolium salt Trop-1 with paraformaldehyde in the presence of ethereal $\mathrm{HCl}^{18}$ We hoped to introduce a more convenient access using the easily accessible (commercially available) Trop-Cl and imidazole.

Scheme 1. Synthesis of unsymmetrical imidazolium salts.

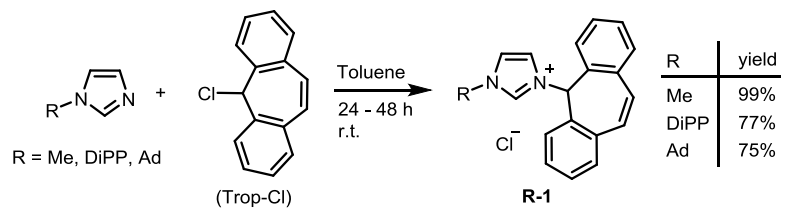

Pleasingly, the reaction of two equivalents of Trop- $\mathrm{Cl}$ and imidazole proceeded within minutes in the presence of one equivalent of triethylamine forming the imidazolium salt Trop-1 cleanly. On a preparative scale, the reaction was carried out in dichloromethane, which proceeded smoothly. Removal of the ammonium salt was achieved by extraction of the reaction mixture with water. Pure product was obtained after subsequent washings of the crude product with dry THF and dry diethyl ether. It is important to note that the sensitivity of the imidazolium salt Trop-1 towards water required the workup to be performed as quickly as possible, before storing the product under an inert atmosphere. Thus, Trop-1 is now quickly accessible in a single step using commercially available imidazole and Trop-Cl (or in three steps starting from dibenzosuberenone) (Scheme 2).

Scheme 2. Old and improved synthesis of ITrop $\cdot \mathrm{HCl}$ (Trop-1).

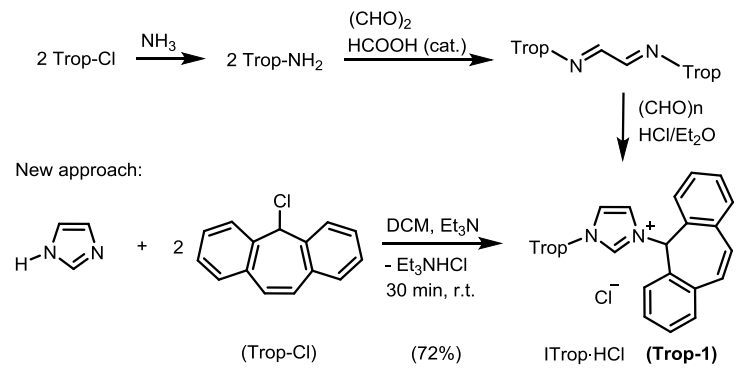

Spectroscopically, the most salient feature of the imidazolium salts is a strongly varying chemical shift value observed for the $2 \mathrm{H}$-imidazolium proton signals in the ${ }^{1} \mathrm{H}$ NMR spectra. While these protons resonate in the expected region above $9 \mathrm{ppm}$ in the $N$-Me- and $N$-Ad-substituted compounds (9.21 and $9.56 \mathrm{ppm}$, respectively), the corresponding signal in DiPP-1 is found at 8.11 ppm and - more surprisingly - at $6.82 \mathrm{ppm}$ for Trop-1. It is likely that this discrepancy in chemical shifts is caused by the shielding effect of the Trop-substitutents aryl moieties. These chemical shifts should not be regarded as indicative of the acidity of these protons since the following complexation reactions did not show substantial differences in reaction times (see below). All resonances of the Trop-unit are observed as sharp signals indicating that only one of the possible endo and exo conformations of the carbocycle is present in solution as previously reported for Tropptype ligands. As this working hypothesis was confirmed for the following metal complexes of the Trop-NHC ligands, the spectroscopic characteristics of the Trop-unit will be discussed in greater detail in the following section.

Synthesis and Steric Features of Gold(I) Chloride Complexes. Next, we targeted the synthesis of gold(I) chloride complexes. These complexes should serve as models for the characterization of the NHCs steric properties and as suitable starting materials for the conversion into cationic gold(I) complexes.

As reported by Grützmacher and coworkers, the isolation of the free ligands is impossible in these systems due to a rapidly occurring rearrangement proceeding most likely via nucleophilic attack of the carbene lone pair on the double bond of the Trop- 
substituent. ${ }^{18,19}$ Therefore, a suitable protocol for the in situ generation/complexation of the ligand had to be found. We sought to apply a mild and convenient protocol for the synthesis of the desired gold(I) chloride complexes, which has recently been introduced by us. ${ }^{20}$ It involves potassium carbonate as the base at $60{ }^{\circ} \mathrm{C}$ using technical grade acetone as solvent under non-inert conditions (Scheme 3).

Scheme 3. Synthesis of Trop-NHC gold(I) chloride complexes.

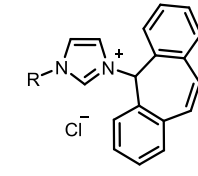

R-1

$\mathrm{R}=\mathrm{Me}, \mathrm{DiPP}, \mathrm{Ad}$, Trop
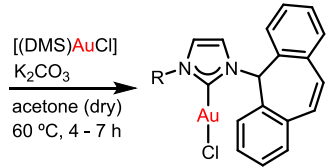

R-2

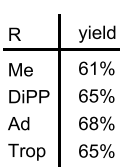

\begin{tabular}{l|l} 
DiPP & $65 \%$ \\
Ad & $68 \%$ \\
Trop & $65 \%$
\end{tabular}

The yields obtained by applying this procedure ranged between $55-61 \%$ after filtering the crude mixtures through a pad of silica gel. Due to the sensitivity of the starting imidazolium salts towards hydrolysis (vide supra), we were hoping to obtain better yields under dry reaction conditions. Unfortunately, these improved only slightly under otherwise identical conditions. However, it was revealed that the sensitivity of the starting materials towards hydrolysis indeed affected the reactions slightly as the formation of Trop-OH was observed when the crude products were analyzed by NMR spectroscopy. We also examined yields following two other common in situ protocols used in the synthesis of NHC-metal complexes: formation of silver adducts followed by subsequent transmetallation ${ }^{21}$ and the addition of a solution of KHMDS to a mixture of the imidazolium salt and the metal precursor at low temperature. ${ }^{22}$ Both procedures proved to be suitable alternatives, yet produced similar yields. Therefore, the least expensive and silver-free protocol involving $\mathrm{K}_{2} \mathrm{CO}_{3}$ as base remains our method of choice for the preparation of these complexes. Despite the moderate yields, all compounds were obtained in analytical purity and did not show any sensitivity towards moisture, which most likely is due to the fact that the neutral imidazolylidene heterocycle represents a poorer leaving group than its imidazolium counterpart in the compounds R-1.

The ${ }^{1} \mathrm{H}$ NMR spectra of the new complexes show the expected patterns displaying the most characteristic resonances such as the olefinic group as a singlet between 6.86-6.97 ppm, the benzylic proton as a singlet between $6.78-6.82 \mathrm{ppm}$, and the aromatic proton of the Trop-unit positioned closest to the imidazole heterocycle as a broad doublet between 7.75-7.90 ppm $(J \sim 7.3 \mathrm{~Hz})$. The other aromatic signals of the Trop-substituent appear as overlapping multiplets between 7.56-7.35 ppm. Only in the case of the $N$ adamantyl-substituted complex Ad-2 is a significant difference with respect to the other compounds signals observed for the benzylic proton which resonates at some $0.3 \mathrm{ppm}$ higher field (7.12 ppm). In comparison to the Trop-unit signals of the imidazolium salts R-1, the most significant difference in chemical shift is found not unexpectedly for the benzylic protons, which here are shifted $0.3-1.4 \mathrm{ppm}$ towards lower field.

Comparing the chemical shifts of the carbenic ${ }^{13} \mathrm{C}\left\{{ }^{1} \mathrm{H}\right\}$ NMR signals of the series DiPP-2, Me-2, Trop-2 and Ad-2, which appear at 173.4, 171.0, 169.7 and $168.1 \mathrm{ppm}$, respectively, reveals that the Trop-unit (secondary $\mathrm{C}$-atom as $\mathrm{N}$-substituent) possesses the expected electron donating influence since the chemical shift of the carbene carbon atom of Trop-2 fits well in between those of the $N$-Me $\left(N-\mathrm{C}^{\text {prim. }}\right)$ and $N$-Ad-substituted compounds $\left(N-\mathrm{C}^{\text {tert. }}\right)$.

In order to gain insight into the steric characteristics of the ligands, all gold(I) chloride complexes were characterized by X-ray diffraction analysis of crystals obtained in each case by slow vapor diffusion of pentane into concentrated solutions of the compounds in chloroform (Figure 2). The different substitution patterns appear to have little influence on the Au- $\mathrm{C}^{\text {carbene }}$ and $\mathrm{Au}$ $\mathrm{Cl}$ bond lengths which range between 1.97-1.99 $\AA$ and 2.27-2.30 $\AA$, respectively, and compare well to other gold(I) chloride complexes of the literature. ${ }^{23}$ The Trop-substituent adopts two major conformations with respect to the rotation around the $\mathrm{N}-\mathrm{C}^{\text {benz. }}$ bond in the solid state structures. This situation leads to important variations in steric shielding of the metal center by the Trop-units aryl-moieties. While in one of the conformations the benzylic $\mathrm{C}-\mathrm{H}$ bond is oriented nearly perpendicular to the NHC plane as seen in Me-2 and DiPP-2, Ad-2 contains the C-H bond nearly within the NHC plane (called "in plane" orientation in the following) while the hydrogen atom is facing in the direction of the metal center. The structural data of Trop-2 further reveal - besides two independent molecules in the unit cell of the crystal lattice - intermediate orientations between both described rotameric forms. In one of these molecules the torsional angles defined by the atoms $\mathrm{C}^{\text {carbene }}$-N-C-H measure 23.1 and $67.4^{\circ}$, while other shows significantly larger values of 44.9 and $92.5^{\circ}$, thus reflecting the much stronger steric shielding of the latter metal center and the flexible steric nature of the system. Notably, the "in plane" orientation of the $\mathrm{C}-\mathrm{H}$ bond while the hydrogen atom faces the opposite direction of the metal center, that would place the olefin donor next to the gold center, was not observed in either structures.

The variable steric influences of the Trop-unit further impose slight distortions of the linear geometry in such a way that the $\mathrm{C} 1$ Au1-Cl1 angles diminish slightly towards the opposite side of the more bulky substituent $\left(\mathrm{R}=\mathrm{Me}\right.$ : $178.09^{\circ}$; DiPP: $177.99^{\circ}$; Ad: $178.26^{\circ}$; Trop $=176.89^{\circ}$ ). The "more bulky" substituent (in the solid state) can be identified best by calculating a steric mapping of each structure using the SambVca software developed in the Cavallo group (Figure 2). ${ }^{24,25}$ Furthermore, the software also permits calculation of the "percent buried volume" $\left(\% V_{\text {bur }}\right)$, a quantitative measure for the steric bulk of a ligand, which was introduced by us in collaboration with the Cavallo group. ${ }^{26}$

Table 1. Comparison of $\mathbf{R - 2}$ with [(NHC)AuCl] analogues.

\begin{tabular}{|c|c|c|}
\hline$[(\mathrm{NHC}) \mathrm{AuCl}]$ & Au-C $C^{\text {carbene }}(\AA)$ & $\% V_{\text {bur }}^{a}$ \\
\hline $\mathrm{NHC}=\mathbf{I} \mathbf{M} \mathbf{e}^{\mathbf{m e} b, c}$ & $1.987(8)$ & 26.2 \\
\hline Me-2 & $1.992(18)$ & 40.2 \\
\hline $\mathrm{NHC}=\mathbf{I A d}^{c}$ & $1.989(2)$ & 39.8 \\
\hline Ad-2 & $1.993(11)$ & 37.5 \\
\hline $\mathrm{NHC}=\mathbf{I P \mathbf { r } ^ { c }}$ & $1.942(3)$ & 44.5 \\
\hline DiPP-2 & $1.972(3)$ & 51.1 \\
\hline $\mathrm{NHC}=\mathbf{I P r}{ }^{* d}$ & $1.987(7)$ & 50.4 \\
\hline Trop-2 & $1.986(3) / 1.990(3)$ & $43.4 / 49.4$ \\
\hline
\end{tabular}

(a) Parameters used in SambVca calcs.: sphere radius: $3.50 \AA$; $\mathrm{Au}$ C1: $2.00 \AA$ A Mesh spacing: 0.05; Bondi radii: 1.17. H atoms excluded. (b) $\mathrm{IMe}^{\mathrm{me}}=1,3,4,5$-tetramethyl-imidazol-2-ylidene. (c) Taken from reference 23. (d) Taken from reference 27c.

As expected, the different orientations of the Trop-substituent arising from the rotation around the $\mathrm{N}-\mathrm{C}^{\text {benz. }}$ bond create drastic variations in the steric shielding of the metal center. The solid state structures containing the Trop-substituents with the $\mathrm{C}-\mathrm{H}$ bond oriented perpendicular to the NHC plane thus correspond to steric mappings where large parts of two quadrants residing on the same side of the steric map are severely hindered (Me-2, DiPP-2, Trop-2). In the case of the DiPP-2 and Trop-2 structures, which contain an additional bulky substituent as opposed to the $N$-Me group in Me-2, significantly crowded situations are obtained with $\% V_{\text {bur }}$ ranging between $43.4-51.1$. 


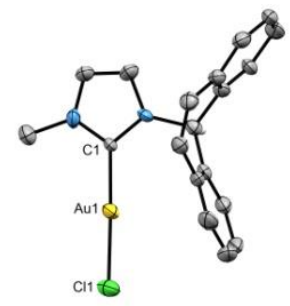

Me-2

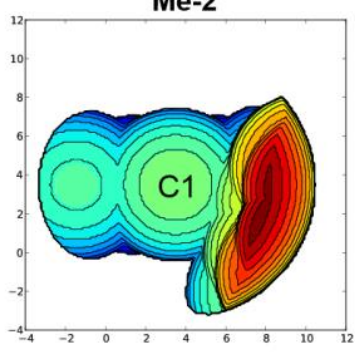

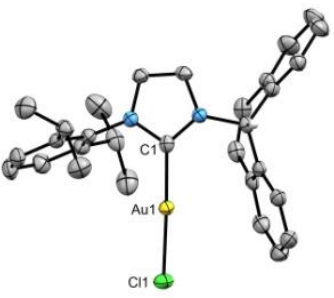

DiPP-2

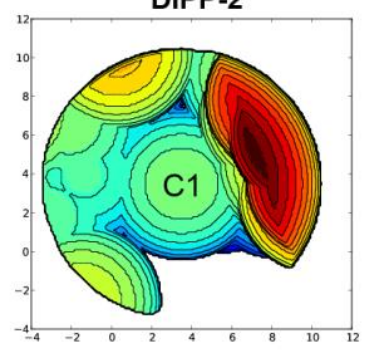

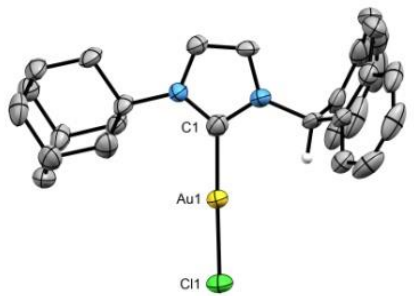

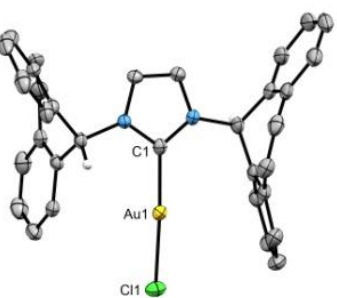

Ad-2

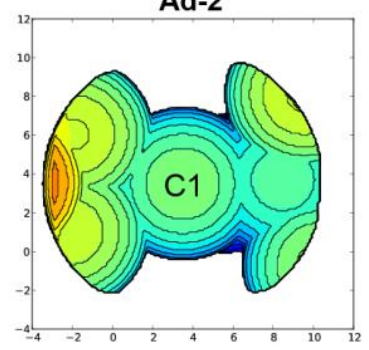

Trop-2

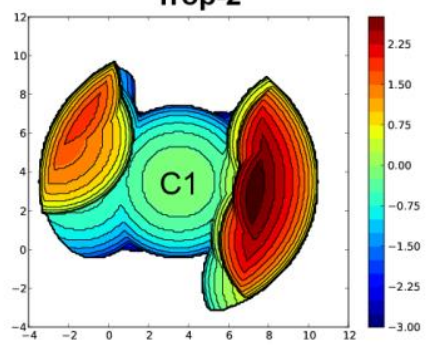

Figure 2. Top row, from left to right: ORTEP plot of the solid state structures of the gold(I) chloride complexes Me-2, DiPP-2, Ad-2 and Trop-2 (only one of the independent molecules found in the unit cell is shown). All hydrogen atoms except for those located at the benzylic positions of the Trop-substituents are omitted for clarity. Thermal ellipsoids are shown at 50\% probability level. Bottom row: Steric mapping corresponding to the above depicted structure with view along the $\mathrm{Au}-\mathrm{C}^{\text {carbene }}$ bond axis.

Comparison of these values with those reported in the literature for two popularly investigated ligands, IPr and its much bulkier analog IPr* (1,3-bis(2,6-diphenylmethyl-4-methylphenyl)imidazol-2-ylidene), ${ }^{27}$ reveal that, in fact, similarly bulky steric environments around the metal center are beeing created by these Trop ligands (see Table 1 ) - at least according to the $\% V_{\text {bur }}$ values of the solid state. Surprisingly, the value calculated for DiPP-2 even slightly exceeds that of IPr*.

However, the limit of the buried volume model, which strictly relies on the solid state structure of metal complexes, becomes evident when comparing these values to that of Ad-2, which contains the least sterically shielding conformation of the Tropsubstituent with respect to the metal center ("in plane" conformation with the $\mathrm{C}^{\text {benzyl. }}-\mathrm{H}$ bond directed towards the metal center). A value of $\% V_{\text {bur }}$ even lower than in the case of Me-2 was calculated (37.5 vs 40.2, respectively), although the spatial requirements of an adamantyl group is certainly substantially higher than that of a methyl group.

With the main characteristics of the individual ligands being elucidated, we set out to convert the gold(I) chloride complexes into compounds incorporating a more electrophilic gold(I) center in order to facilitate gold olefin interactions. For this study we chose two halide abstracting agents containing weakly coordinating anions with largely differing abilities to coordinate to metal center: $\mathrm{NaBArF}_{24}$ (practically not coordinating) ${ }^{28}$ and $\mathrm{AgNTf}_{2}$ (giving rise to weakly bound $N$-metalated complexes). ${ }^{12}$

Scheme 4: Synthesis of Gagosz-type complexes R-3.<smiles></smiles>

R-2

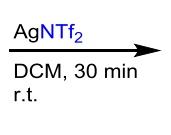
r.t.

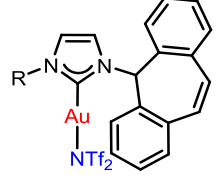

R-3

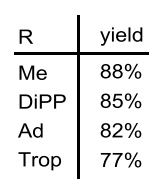

In accordance with the reported procedure, the neutral complexes R-3 were obtained in good yields by stirring equimolar mixtures of the gold(I) chloride complexes R-2 and $\mathrm{AgNTf}_{2}$ in dichloromethane at room temperature for 15 - $30 \mathrm{~min}$ (Scheme 4). ${ }^{12}$ All compounds proved crystalline, air-stable materials which were obtained analytically pure. In the case of Me-3, slow de- composition was observed in $\mathrm{CDCl}_{3}$ solution over the course of a few days and in the solid state over several weeks. The coordination of the $\mathrm{NTf}_{2}$ anion to the gold(I) center was confirmed for all compounds by X-ray diffraction analysis of crystals obtained by slow vapor diffusion of pentane into concentrated $\mathrm{CHCl}_{3}$ solutions.

In agreement with NMR data, which do not show any significant shifts of the olefin unit in the ${ }^{1} \mathrm{H}$ and ${ }^{13} \mathrm{C}\left\{{ }^{1} \mathrm{H}\right\}$ spectra in comparison to the signals of $\mathbf{R - 2}$, an interaction between the olefin moiety and the metal center was not detected. In fact, the Trop-units signals in the ${ }^{1} \mathrm{H}$ NMR spectra appear at nearly the same chemical shifts as in $\mathbf{R - 2}$, while only the imidazolylidene protons experience minor low-field shifts of about $0.1 \mathrm{ppm}$ indicating the more electrophilic nature of the gold(I) center. However, a profound steric influence of the Trop-substituent on the bulky anion is noticeable in the solid-state structures of these complexes (Figure 3). As a function of the conformation of the Trop-unit, different torsion angles between the NHC-plane and the $\mathrm{NTf}_{2}^{-}$are observed. This can be quantified roughly by the torsional angles defined by the sulfur atoms of the $\mathrm{NTf}_{2}$ anion and the heterocycle nitrogen atoms (for details, see Table 2). Thus, in the structure of Ad-3, in which the Trop-substituent again adopts the "least bulky" conformation as in its chloride analog Ad-2 ( $\mathrm{C}^{\text {benz. }}-\mathrm{H}$ bond within the NHC plane), the $\mathrm{NTf}_{2}{ }^{-}$is twisted only slightly with respect to the NHC plane. The other solid-state structures show the Trop-substituent in the "more bulky" conformations leading to notable distortions of the complex geometry due to steric interaction with the $\mathrm{NTf}_{2}^{-}$unit. While in DiPP-3, again containing the "most bulky" Trop-orientation $\left(\mathrm{C}^{\text {benz. }}-\mathrm{H}\right.$ bond perpendicular to NHC plane), the $\mathrm{NTf}_{2}$ is oriented nearly perpendicular to the NHC-plane (as exemplified by the torsional angle defined by the atoms S1-S2-N5-N2 of $93.47^{\circ}$ ), the "intermediately bulky conformations" in Me-3 and Trop-3 lead to smaller distortions (130.48 and $123.73^{\circ}$, respectively; see Table 2 for details). ${ }^{29}$ While these repulsive interactions between the expansive Trop-moiety and the $\mathrm{NTf}_{2}^{-}$ligand do not seem to significantly affect the Au-N bond distances, the deviation from the ideal linear geometry indeed is greatest in the DiPP-3 and Trop-3 complexes (5.2 and $4.9^{\circ}$, respectively), which possess the smallest torsional angles (see Table 2). 


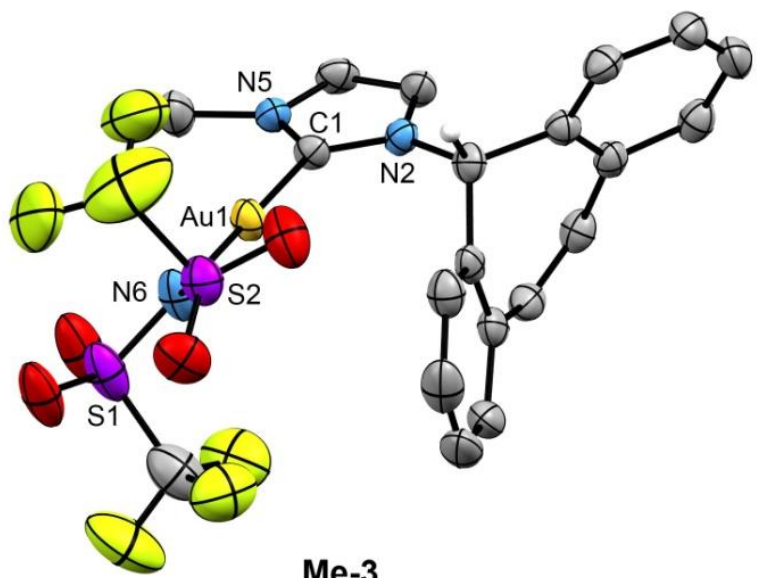

Me-3

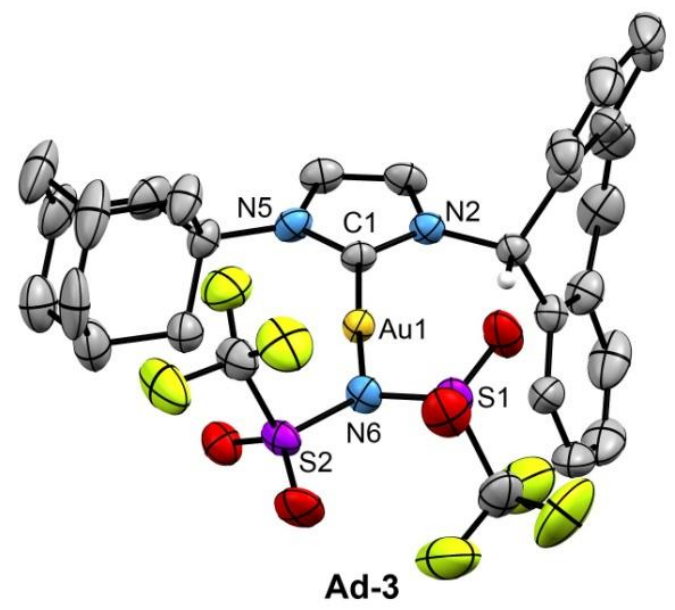

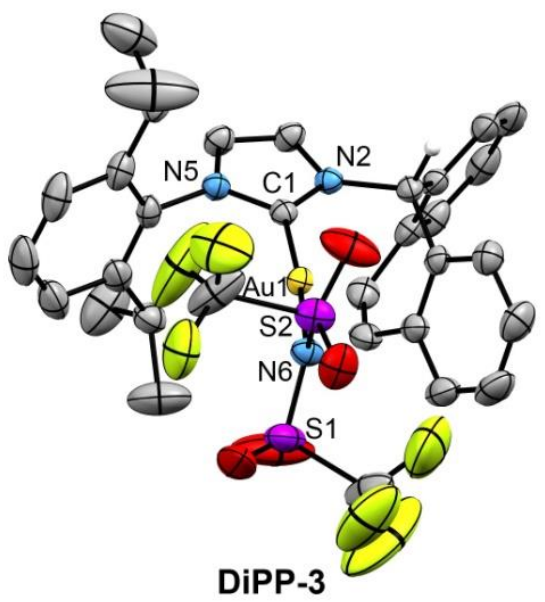

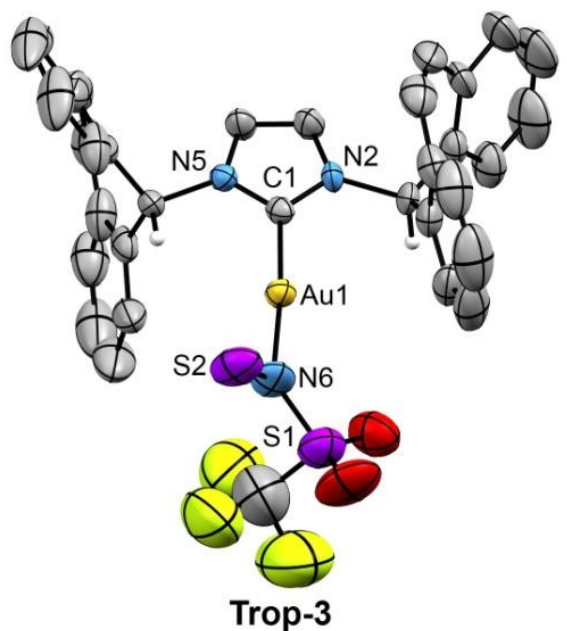

Figure 3. ORTEP plot of the solid-state structures of Me-3 (top left), DiPP-3 (top right), Ad-3 (bottom left) and Trop-3 (the $\mathrm{CF}_{3}$ group at S2 showed disorder and is omitted for clarity) gold complexes. Solvent molecules and hydrogen atoms except for those located at the benzylic positions of the Trop-substituents are omitted for clarity. Thermal ellipsoids are shown at 50\% probability level.

Table 2. Important spectroscopic and structural parameters of the gold(I) compounds of this study.

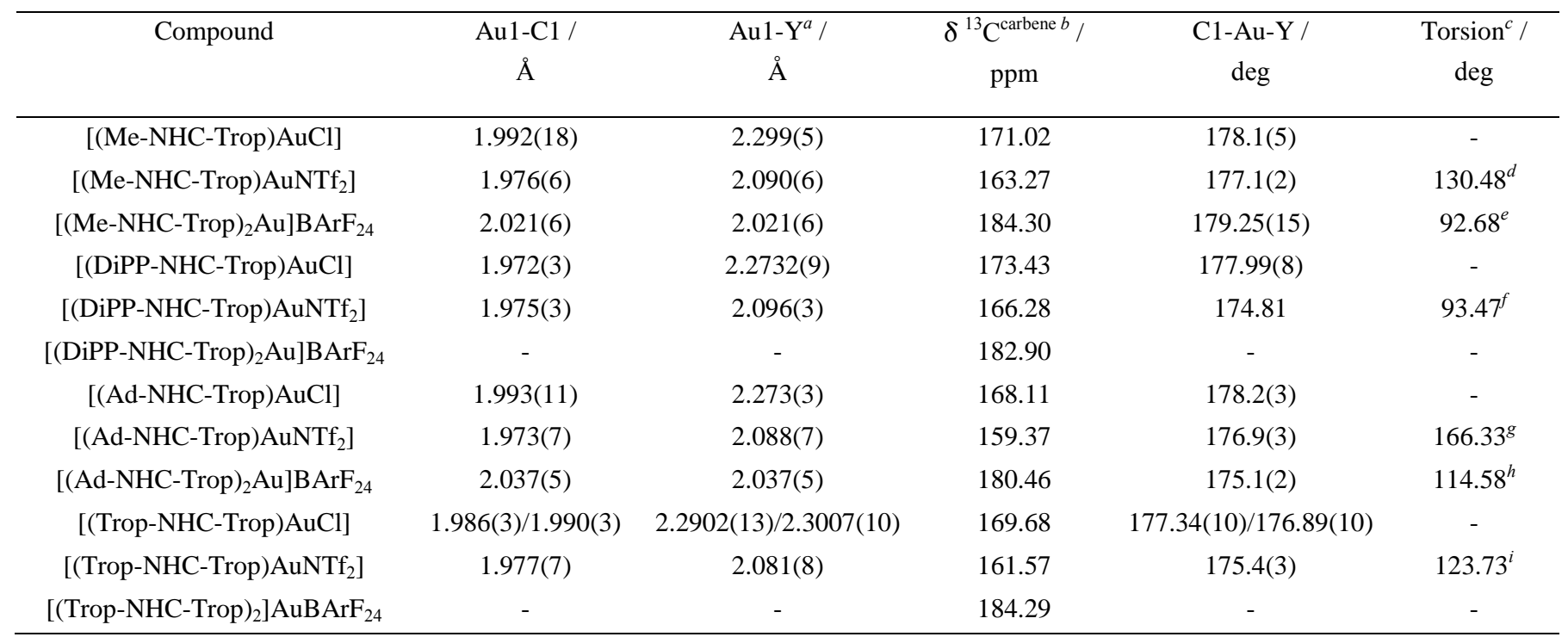

$\mathrm{Y}=\mathrm{Cl1}$, N6 or $\mathrm{C}^{\text {carbene }}$. (b) Measured in $\mathrm{CDCl}_{3}$. (c) Torsionals angles are defined by the following atoms: (d) S1-S2-N5-N2; (e) N2-N5N2 ${ }^{\mathrm{I}}-\mathrm{N}{ }^{\mathrm{I}}$; (f) S1-S2-N5-N2; (g) S1-S2-N2-N5; (h) N2-N5-N32-N35; (i) S1-S2-N2-N5. 
In the ${ }^{13} \mathrm{C}\left\{{ }^{1} \mathrm{H}\right\}$ NMR spectra, the same decreasing order of chemical shift values of the carbene carbon signals was observed for the series DiPP-3, Me-3, Trop-3 and Ad-3, as seen before for the corresponding chloride complexes R-2 (Table 2), which corroborates their classification as being as fairly electron-rich $N$ alkyl-substituted NHC-donors.

Scheme 5. Formation of cationic gold complexes R-4.
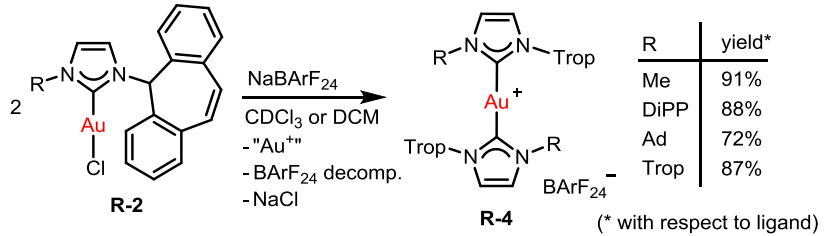

Our investigations into the conversion of the gold(I) chloride complexes with $\mathrm{NaBArF}_{24}$ began by monitoring the reactions by in situ $\mathrm{NMR}$ spectroscopy in $\mathrm{CDCl}_{3}$ (Scheme 5). Addition of the solvent to a mixture of $\mathrm{NaBArF}_{24}$ and Me-2 immediately led to the formation of a purple coloring and a black precipitate. ${ }^{1} \mathrm{H}$ NMR spectroscopy recorded shortly thereafter indicated the formation of a new NHC-containing species (imidazolylidene signals at higher field: 6.58 and $6.27 \mathrm{ppm}$ ) next to multiple new signals in the $\mathrm{BArF}_{24}{ }^{-}$region at lower field than $7.5 \mathrm{ppm}$. In accordance with this, ${ }^{19} \mathrm{~F}$ NMR spectroscopy showed several new fluorinecontaining species close to the $\mathrm{BArF}_{24}$ resonance, which roughly integrated to the same value as the new signals combined (see Supporting Information). Washing of the crude product with pentane was able to reduce these fluoride-containing byproducts to trace amounts and made clear that the new compound consisted of a ligand to $\mathrm{BArF}_{24}{ }^{-}$ratio of $2: 1$. Therefore, it seemed most likely that the corresponding cationic bis-NHC complex had formed under loss of highly reactive, "naked" cationic gold(I), which presumably is responsible for the immediate reaction with the $\mathrm{BArF}_{24}$ anion until all of it is consumed. The occurrence of the carbene signal in the ${ }^{13} \mathrm{C}\left\{{ }^{1} \mathrm{H}\right\}$ NMR spectrum at $184.3 \mathrm{ppm}$ was also in accord with the formation of a cationic, bis-NHC-coordinated complex. ${ }^{30}$ Olefin-coordinated species were not detected.

Further purification of the compound was achieved by filtration through silica gel using dichloromethane. This further treatment permitted to obtain pure material as gauge by elemental analysis and also allowed single crystals to be grown for X-ray diffraction analysis by slow vapor diffusion of pentane into a solution of the compound in $\mathrm{CHCl}_{3}$ revealing the expected cationic structure (Figure 4).

For the more bulky complexes of the series, we hoped that possible olefin-stabilized cationic gold species would be more favored over the bimolecular decomposition products. However, similar in situ ${ }^{1} \mathrm{H}$ and ${ }^{19} \mathrm{~F}$ NMR spectra were obtained showing the decomposition products of the $\mathrm{BArF}_{24}$ anion in nearly the same ratios as before. Notably, full conversion of the starting complexes was only obtained after stirring at room temperature overnight, but intermediate species were again not detected. The larger scale reactions were carried out in dichloromethane as solvent and workup proceeded in each case similarly to the method used for Me-1. All compounds were obtained in good to high yields (with respect to the starting ligand) and were fully characterized spectroscopically and by elemental analysis.

Obviously, bimolecular decomposition is strongly favored over the formation of ligand-chelated structures - at least in the case of metal complexes bearing NHC ligands which do not exceed buried volumes of approximately $50 \%$. It can only be postulated that a much greater steric demand of the second $N$-substituent is required in order to sufficiently stabilize a possible olefincoordinated species. Eventhough bimolecular decomposition is well known to accompany the formation of cationic (NHC)gold(I) complexes, ${ }^{31}$ clean and quantitative formation of these complexes was nevertheless surprising to us (no NHC-containing side products were observed). The lower than theoretical yields are simply a consequence of the extensive purification (washing, filtration and - if needed - recrystallization) required in order to remove the decomposition products of the $\mathrm{BArF}_{24}$ anion.

In order to exclude that the formation of these byproducts are not just specific to the Trop-NHC systems of this study, a control experiment was conducted using [Au(IAd)Cl]. In situ NMR spectroscopy in $\mathrm{CDCl}_{3}$ revealed an identical signal pattern for the formed fluorinated aryl compounds in the ${ }^{19} \mathrm{~F}$ NMR and the ${ }^{1} \mathrm{H}$ NMR spectrum again showed the clean formation of the corresponding cationic bis-NHC complex, next to the same new signals at low field below $7.5 \mathrm{ppm}$. It must therefore be assumed that the "naked" gold fragments formed in activations of (NHC) $\mathrm{Au}(\mathrm{I})$ chloride complexes by $\mathrm{NaBArF}_{24}$ are rapidly reduced to colloidal gold by reaction with the borate salt. The cleavage of a $\mathrm{C}-\mathrm{B}$ bond of the $\mathrm{BArF}_{24}$ anion by a cationic gold fragment has recently been reported by Straub and coworkers and supports this conclusion. ${ }^{32}$ Due to the extreme steric bulk of the NHC ligand employed in their study, the bond activation proceeds only slowly over several days.

For complex Ad-4, we were again able to grow crystals suitable for X-ray diffraction analysis by layering a $\mathrm{CHCl}_{3}$ solution of the compound with pentane (Figure 4). While in the previous solidstate structures the complex geometry was governed mainly by the Trop-substituents expansive orientation towards the metal center, the bis-NHC-ligated complexes reveal that the second $\mathrm{N}$ substituent can also have a significant impact. Figure 4 shows the solid-state structures of Me-4 and Ad-4 that demonstrate that the presence of the large $\mathrm{N}$-Ad group leads to a repulsion with the Trop-substituents of the opposing NHC-ligand. Consequently, a nearly perpendicular orientation of the NHC-planes as in Me-4 is not feasible in Ad-4 leading to the increasde of the angle between the NHC planes to some $115^{\circ}$. This steric interaction further becomes apparent in the lengthening of the $\mathrm{C}^{\text {carbene }}$-Au bonds from ca. $2.02 \AA$ in Me-4 to $2.04 \AA$ in Ad-4.

Preliminary Catalytic Study. Although the ligands have so far not been able to reveal olefin-gold interactions, their strongly variable steric demands maintained our interest in investigating their application in catalysis. Keeping the significant influence of the Trop-moiety on the opposing coordinating $\mathrm{NTf}_{2}{ }^{-}$unit in mind, a beneficial influence on catalysis was envisaged for the Gagosztype complexes R-3. It has been postulated that a substantial steric congestion of the NHC ligand leads to more facile dissociation of the $\mathrm{NTf}_{2}$ anion, thus leading to higher activities due to the increase in concentration of the catalytically active gold cation $[\mathrm{AuL}]^{+}{ }^{33}$

As typical benchmark reaction, the hydration of alkynes - more specifically of diphenylacetylene - was chosen. ${ }^{34}$ Quickly it became clear that only precatalyst DiPP-3 was considerably active in this reaction showing full conversion at $2.5 \mathrm{~mol} \%$ catalyst loading after $24 \mathrm{~h}$ (Table 3, Entry 5). The reactions involving the other precatalysts indicated rapid decomposition of the complexes by the formation of black precipitates within the first minutes. Thus, even at $5 \mathrm{~mol} \%$ catalyst loading complexes Me-3 and Trop-3 showed no conversion of the substrate, while Ad-3 showed little catalytic activity ( $9 \%$ conversion after $24 \mathrm{~h}$ ).

Interestingly, the parent systems to the DiPP- and Adsubstituted Trop-ligands of this study, $\left[\mathrm{Au}(\mathrm{IPr})\left(\mathrm{NTf}_{2}\right)\right]$ and [Au(IAd) $\left.\left(\mathrm{NTf}_{2}\right)\right]$, provided some insights into the nature of this reactivity trend. As the IAd-based pre-catalyst performs similarly to Ad-3 (also 9\% conversion) but not as poorly as Me-3 and Trop-3, it seems that even very bulky tertiary alkyl $N$-substituents are not well-tolerated in water-inclusive gold(I) catalysis. The systems bearing $N$-substituents which are most susceptible to 

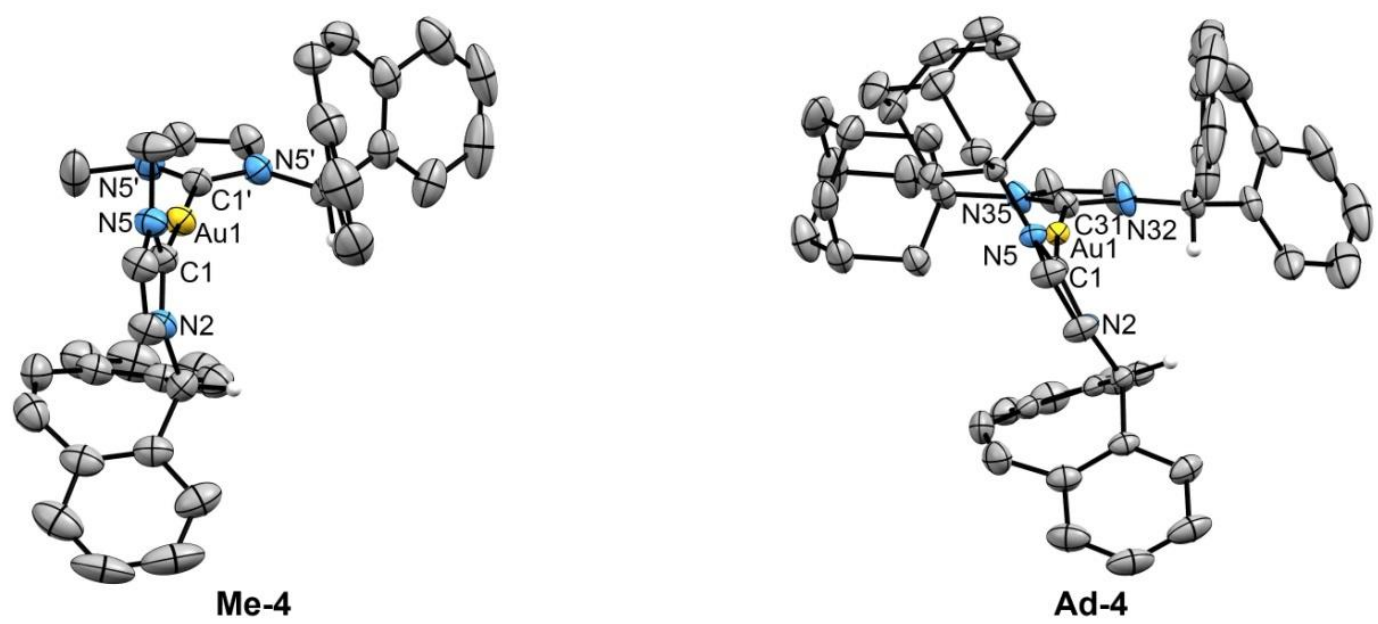

Figure 4. ORTEP plot of the solid-state structures of Me-4 (left) and Ad-4 (right). All hydrogen atoms except for those located at the benzylic positions of the Trop-substituents, counterions and solvent molecules are omitted for clarity. Thermal ellipsoids are shown at 50\% probability level.

hydrolysis Me-3 and Trop-3 therefore do not show any catalytic activity. In this regard, it is not surprising that DiPP-2, bearing one hydrolysis-resistant $N$-substituent, shows drastically enhanced catalytic activity over Ad-3, but is far less effective than its parent catalyst system $\left[\mathrm{Au}(\mathrm{IPr})\left(\mathrm{NTf}_{2}\right)\right]$ (Table 3, Entry 4).

Table 3. Hydration of diphenylacetylene. ${ }^{\mathrm{a}}$

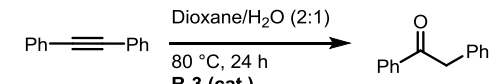

\begin{tabular}{clcc}
\hline Entry & {$\left[\mathrm{Au}(\mathrm{NHC})\left(\mathrm{NTf}_{2}\right)\right]$} & Loading $(\mathrm{mol} \%)$ & ${\text { Conv. }(\%)^{a}}^{a}$ \\
\hline 1 & Me-3 & 5 & 0 \\
2 & $\mathrm{NHC}=\mathrm{IAd}^{b}$ & 5 & 9 \\
3 & Ad-3 & 5 & 9 \\
4 & NHC $=\mathrm{IPr}^{c}$ & 0.25 & $88^{d}$ \\
5 & DiPP-3 & 2.5 & $>99$ \\
6 & DiPP-3 & 2.0 & 86 \\
7 & Trop-3 & 5 & 0 \\
\hline
\end{tabular}

(a) Determined by GC; averaged values of two runs (b) Prepared according to ref. 12b. (c) Prepared according to ref. 13 (d) after 3 $\mathrm{h}$ reaction time.

\section{CONCLUSION}

In summary, a series of new gold(I) complexes bearing dibenzotropylidene-functionalized NHC ligands have been accessed starting from the corresponding imidazolium chloride salts (R-1), which are accessible in a single step from $N$-substituted imidazoles $(N$-alkyl, $N$-aryl or $N$-H) and Trop-Cl. The steric features of the ligands were evaluated in the solid-state structures of the gold(I) chloride complexes R-2 which revealed drastically varying steric shielding of the metal center depending on the orientation of the Trop-moiety. This was visualized by calculating the steric mapping of these complexes and quantified by the $\% V_{\text {bur }}$ values. The most bulky ligand showed a surprisingly high $\% V_{\text {bur }}$ of $51.1 \%$, thus surpassing even the value calculated for one of the most commonly used very bulky NHC ligand IPr*.
Reacting the gold(I) chloride complexes (R-2) with halide abstractors such as $\mathrm{AgNTf}_{2}$ and $\mathrm{NaBArF}_{24}$ led to the formation of the Gagosz-type complexes (R-3) and cationic bis-NHC-ligated complexes of the type $\left[\mathrm{Au}(\mathrm{NHC})_{2}\right] \mathrm{BArF}_{24}(\mathbf{R}-\mathbf{4})$, respectively. Unfortunately, an interaction between the olefin-unit of the ligands and the gold center was never observed, however the Tropunit's significant steric impacts on the $\mathrm{NTf}_{2}$ ligands implicated their potential application in catalysis.

However, it was revealed that - at least for water-inclusive gold(I) catalysis - the catalysts lack sufficient stability for efficient catalysis (as another common symmetrical $\mathrm{N}$-alkyl-substituted NHC ligand did as well). Full conversion was only achieved for the $N$-Aryl substituted precatalyst DiPP-3, presumably due to its decreased sensitivity towards hydrolysis under the reaction conditions. We are currently exploring the activity of these complexes in non water-inclusive catalytic reactions.

Due to the highly flexible nature of the Trop-NHC system, our future efforts will be directed towards the design of new ligands with restricted rotation around the $\mathrm{N}-\mathrm{C}^{\text {Trop }}$ bonds in order to preorganize chelation of the ligand. We believe the simple synthetic access to the Trop-substituted imidazolium salts will be key in finding suitable alternatives.

\section{EXPERIMENTAL}

General Information on reagents and synthetic details, X-ray diffraction data and details for data collection can be found in the supporting information.

Preparation of "(Me-NHC-Trop)$\cdot \mathbf{H C l}$ " (Me-1). Under inert gas atmosphere, $N$-Me-imidazole $(2.19 \mathrm{~g} 26.7 \mathrm{mmol})$ was added slowly to a solution of Trop-Cl $(5.50 \mathrm{~g}, 24.3 \mathrm{mmol})$ in dry toluene $(150 \mathrm{ml})$ in a $250-\mathrm{ml}$ round-bottom flask. The mixture was stirred for $24 \mathrm{~h}$ leading to the precipitation of a white solid which was collected on a frit under inert conditions, washed with toluene $(5 \times 100 \mathrm{ml})$ and then dried under vacuum at $50{ }^{\circ} \mathrm{C}$ for $72 \mathrm{~h}$. Me-1 was obtained as a very hygroscopic white powder (7.4 g, 99\% yield). ${ }^{1} \mathrm{H}$ NMR $(500.13 \mathrm{MHz}$, $\left.\mathrm{CDCl}_{3}\right): 9.21(\mathrm{~s}, \quad \mathrm{NCHN}), \quad 7.91\left(\mathrm{bd},{ }^{3} J_{\mathrm{HH}}=7.3 \mathrm{~Hz}, \quad 2 \mathrm{H}\right.$, $\left.\mathrm{C}^{\text {benz }} \mathrm{C}^{\text {quart. }} \mathrm{C}^{\mathrm{Ar}} H\right), 7.58-7.48\left(\mathrm{~m}, 6 \mathrm{H}, \mathrm{C}^{\mathrm{Ar}} H\right), 7.20\left(\mathrm{~d},{ }^{3} J_{\mathrm{H}, \mathrm{H}}=1.5 \mathrm{~Hz}\right.$, $1 \mathrm{H}, \mathrm{MeNCHCHN}), 7.06$ (s, $\left.1 \mathrm{H}, \mathrm{C}^{\text {benz. }} H\right), 6.94$ (s, $\left.2 \mathrm{H}, \mathrm{C}^{\text {olef. }} H\right), 6.56$ (d, $\left.{ }^{3} J_{\mathrm{HH}}=1.7 \mathrm{~Hz}, 1 \mathrm{H}, \mathrm{MeNCHCHN}\right), 3.95(\mathrm{~s}, 3 \mathrm{H}, M e \mathrm{~N}),{ }^{13} \mathrm{C}\left\{{ }^{1} \mathrm{H}\right\}$ DEPTQ NMR (125.76 MHz, $\left.\mathrm{CDCl}_{3}\right): 137.43$ (NCHN), 134.21 $\left(\underline{C}^{\text {quart.trop }}\right), 132.32\left(\underline{C}^{\text {quart.trop }}\right), 131.44\left(\mathrm{C}^{\text {benz. }} \mathrm{C}^{\text {quart. }} \underline{C}^{\mathrm{Ar}} \mathrm{H}\right), 130.84+$ 
$130.79\left(\underline{\mathrm{C}}^{\text {olef. }} H+\underline{\mathrm{C}}^{\mathrm{Ar}} \mathrm{H}\right), 130.23\left(\underline{\mathrm{C}}^{\mathrm{Ar}} \mathrm{H}\right), 130.09\left(\underline{\mathrm{C}}^{\mathrm{Ar}} \mathrm{H}\right), 122.21$ (s, MeNCHCHN), 121.47 (s, MeNCHCHN), 69.33 ( $\left.\mathrm{C}^{\text {benz. }} \mathrm{H}\right), 36.95$ $\left(\left(\mathrm{H}_{3} \underline{\mathrm{C}}\right) \mathrm{N}\right)$. MS (ESI $\left.{ }^{+}, \mathrm{MeCN}\right)$ : Calcd.: $273.14\left(\mathrm{M}^{-\mathrm{Cl}^{+}}\right), 191.09$ (dibenzotropylium cation); Found: 273.21, 191.14.

Preparation of "(DiPP-NHC-Trop) $\cdot \mathbf{H C l}$ " (DiPP-1). Under argon, a solution of Trop-Cl $(227 \mathrm{mg}, 1.00 \mathrm{mmol})$ in dry toluene $(4 \mathrm{ml})$ was added slowly to a solution of $N$-DiPP-imidazole $(251 \mathrm{mg}, 1.10 \mathrm{mmol})$ in dry toluene $(6 \mathrm{ml})$. The mixture was stirred for 2 days leading to the precipitation of a white solid which was collected on a frit and washed with dry toluene $(2 \times 5 \mathrm{ml})$, then with dry diethyl ether $(3 \times 10 \mathrm{ml})$. The solid remaining on the frit was dried in a stream of nitrogen (to avoid formation of a sticky oil due to the hygroscopic behavior of the substance) and then under vacuum at $80^{\circ} \mathrm{C}$ for 3 days to give the title compound as a white powder $\left(350 \mathrm{mg}, 77 \%\right.$ yield). ${ }^{\mathrm{H}} \mathrm{H}$ $\mathrm{NMR}\left(500.13 \mathrm{MHz}, \mathrm{CDCl}_{3}\right): 8.38$ (ps.d, $J_{\mathrm{HH}}=7.6 \mathrm{~Hz}, 2 \mathrm{H}$ $\left.\mathrm{C}^{\text {benz. }} \mathrm{C}^{\text {quart. }} \mathrm{C}^{\mathrm{Ar}} H\right), 8.22\left(\mathrm{~s}, 1 \mathrm{H}, \mathrm{C}^{\text {benz. }} H\right), 8.11(\mathrm{~s}, 1 \mathrm{H}, \mathrm{NCHN}), 7.60-$ $7.55\left(\mathrm{~m}, 2 \mathrm{H}, \mathrm{C}^{\mathrm{Ar}} H\right), 7.50-7.42\left(\mathrm{~m}, 5 \mathrm{H}, 4 \mathrm{C}^{\mathrm{Ar}} H+p-\mathrm{C}^{\mathrm{DiPP}} \mathrm{H}\right), 7.21(\mathrm{~d}$, $\left.{ }^{3} J_{\mathrm{HH}}=7.9 \mathrm{~Hz}, 2 \mathrm{H}, m-\mathrm{C}^{\mathrm{DiPP}} \mathrm{H}\right), 7.07\left(\mathrm{t},{ }^{3} J_{\mathrm{H}, \mathrm{H}}=1.7 \mathrm{~Hz}, 1 \mathrm{H}\right.$, DiPP$\mathrm{NCHCHN}), 6.97\left(\mathrm{t},{ }^{3} J_{\mathrm{H}, \mathrm{H}}=1.8 \mathrm{~Hz}, 1 \mathrm{H}, \mathrm{DiPP}-\mathrm{NCHCHN}\right), 6.94(\mathrm{~s}, 2 \mathrm{H}$, $\left.\mathrm{C}^{\text {olef. }} \mathrm{H}\right), 2.30\left(\mathrm{sept},{ }^{3} \mathrm{~J}_{\mathrm{HH}}=6.8 \mathrm{~Hz}, 2 \mathrm{H}, \mathrm{CH}\left(\mathrm{CH}_{3}\right)_{2}\right), 1.09\left(\mathrm{~d},{ }^{3} J_{\mathrm{HH}}=\right.$ $\left.6.6 \mathrm{~Hz}, 12 \mathrm{H}, 2 \times \mathrm{CH}\left(\mathrm{CH}_{3}\right)_{2}\right) .{ }^{13} \mathrm{C}\left\{{ }^{1} \mathrm{H}\right\}$ DEPTQ NMR $(125.76 \mathrm{MHz}$, $\left.\mathrm{CDCl}_{3}\right): 145.70\left(\mathrm{C}^{\mathrm{DiPP}}-\mathrm{N}\right), 137.00(\mathrm{NCHN}), 134.08\left(\underline{\mathrm{C}}^{\text {quart.trop }}\right), 133.17$ $\left(\mathrm{C}^{\text {quart.trop }}\right), \quad 132.69 \quad\left(\mathrm{C}^{\text {benz. }} \mathrm{C}^{\text {quart. }} C^{\mathrm{Ar}} \mathrm{H}\right), \quad 131.83\left(p-\mathrm{C}^{\mathrm{DiPP}} \mathrm{H}\right), 130.72$ $\left(\underline{\mathrm{C}}^{\text {olef. }} \mathrm{H}\right), 130.52\left(\underline{\mathrm{C}}^{\mathrm{Ar}} \mathrm{H}\right), 130.17\left(\underline{\mathrm{C}}^{\mathrm{Ar}} \mathrm{H}\right), 129.80\left(\underline{\mathrm{C}}^{\mathrm{Ar}} \mathrm{H}\right), 124.72(\mathrm{~m}-$ $\left.\underline{\mathrm{C}}^{\mathrm{DiPP}} \mathrm{H}\right), 123.14$ (s, DiPP-NCHCHN), 122.54 (s, DiPP-NCHCHN), $68.51\left(\underline{\mathrm{C}}^{\text {benz }} \mathrm{H}\right), 28.51\left(\underline{\mathrm{CH}}\left(\mathrm{CH}_{3}\right)_{2}\right), 24.55\left(\mathrm{CH}\left(\mathrm{CH}_{3}\right)^{\mathrm{a}}\left(\mathrm{CH}_{3}\right)^{\mathrm{b}}\right), 24.38$ $\left(\mathrm{CH}\left(\mathrm{CH}_{3}\right)^{\mathrm{a}}\left(\mathrm{CH}_{3}\right)^{\mathrm{b}}\right)$. MS (ESI $\left.{ }^{+}, \mathrm{MeCN}\right)$ : Calcd.: $419.25\left(\mathrm{M}-\mathrm{Cl}^{+}\right)$, 191.09 (dibenzotropylium cation); Found: 419.24, 191.08.

Preparation of "(Ad-NHC-Trop)$\cdot \mathbf{H C l}$ ” (Ad-1). Under argon, a solution of Trop-Cl $(227 \mathrm{mg}, 1.00 \mathrm{mmol})$ in dry toluene $(4 \mathrm{ml})$ was added slowly to a solution of $\mathrm{N}$-Ad-imidazole $(222 \mathrm{mg}, 1.10 \mathrm{mmol})$ in dry toluene $(6 \mathrm{ml})$. The mixture was stirred for $24 \mathrm{~h}$ leading to the precipitation of a sticky white solid which was triturated with dry THF $(2 \times 5 \mathrm{ml})$, a mixture of dry THF/diethyl ether $(2: 1,1 \times 5 \mathrm{ml})$ and finally dry diethyl ether $(1 \times 5 \mathrm{ml})$. The solid was dried under vacuum at $50{ }^{\circ} \mathrm{C}$ for 3 days to give the title compound as a white powder (322 mg, 75\% yield). ${ }^{1} \mathrm{H}$ NMR $\left(400.30 \mathrm{MHz}, \mathrm{CDCl}_{3}\right): 9.56$ (s, $1 \mathrm{H}, \mathrm{NCHN}), 8.23$ (ps.d, $\left.J_{\mathrm{HH}}=7.5 \mathrm{~Hz}, 2 \mathrm{H}, \mathrm{C}^{\text {benz. }} \mathrm{C}^{\text {quart. }} \mathrm{C}^{\mathrm{Ar}} H\right), 7.83(\mathrm{~s}$, $\left.2 \mathrm{H}, \mathrm{C}^{\text {benz. }} H\right), 7.58-7.50\left(\mathrm{~m}, 2 \mathrm{H}, \mathrm{C}^{\mathrm{Ar}} H\right), 7.49-7.42\left(\mathrm{~m}, 4 \mathrm{H}, \mathrm{C}^{\mathrm{Ar}} H\right)$, 7.11 (s, $\left.1 \mathrm{H}, \mathrm{C}^{\mathrm{Imi}} H\right), 6.96\left(\mathrm{~s}, 1 \mathrm{H}, \mathrm{C}^{\text {olef. }} H\right), 6.87$ (bs, $\left.1 \mathrm{H}, \mathrm{C}^{\mathrm{Imi}} H\right), 2.23(\mathrm{~s}$, $\left.3 \mathrm{H}, \mathrm{C}^{\mathrm{Ad}} H\right), 2.00\left(\mathrm{~s}, 6 \mathrm{H}, \mathrm{C}^{\mathrm{Ad}} H_{2}\right), 1.71\left(\mathrm{~s}, 6 \mathrm{H}, \mathrm{C}^{\mathrm{Ad}} H_{2}\right) .{ }^{13} \mathrm{C}\left\{{ }^{1} \mathrm{H}\right\}$ DEPTQ

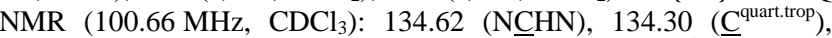
$133.35\left(\underline{C}^{\text {quart.trop }}\right), 132.60\left(\mathrm{C}^{\text {benz. }} \mathrm{C}^{\text {quart. }} \mathrm{C}^{\mathrm{Ar}} \mathrm{H}\right), 131.03\left(\mathrm{C}^{\text {olef. }} \mathrm{H}\right), 130.41$ $\left(\underline{\mathrm{C}}^{\mathrm{Ar}} \mathrm{H}\right), 130.36\left(\underline{\mathrm{C}}^{\mathrm{Ar}} \mathrm{H}\right), 129.64\left(\underline{\mathrm{C}}^{\mathrm{Ar}} \mathrm{H}\right), 121.69\left(\mathrm{~s}, \underline{\mathrm{C}}^{\mathrm{Imi}} \mathrm{H}\right), 116.80(\mathrm{~s}$, $\left.\underline{\mathrm{C}}^{\mathrm{Imi}} \mathrm{H}\right), 68.26\left(\underline{\mathrm{C}}^{\text {benz. }} \mathrm{H}\right), 60.36\left(\underline{\mathrm{C}}^{\text {quart. }}-\mathrm{N}\right), 42.75\left(\underline{\mathrm{C}}^{\mathrm{Ad}} \mathrm{H}_{2}\right), 35.39$ $\left(\underline{\mathrm{C}}^{\mathrm{Ad}} \mathrm{H}_{2}\right), 29.45\left(\underline{\mathrm{C}}^{\mathrm{Ad}} \mathrm{H}\right)$. MS (ESI $\left.{ }^{+}, \mathrm{MeCN}\right)$ : Calcd.: $393.23\left(\mathrm{M}-\mathrm{Cl}^{+}\right)$, 191.09 (dibenzotropylium cation); Found: 393.20, 191.04.

Preparation of "(Trop-NHC-Trop)·HCl” (Trop-1). Under argon, a solution of Trop-Cl $(499 \mathrm{mg}, 2.20 \mathrm{mmol})$ in dry DCM $(5 \mathrm{ml})$ was added slowly to a solution of imidazole $(68.1 \mathrm{mg}, 1.00 \mathrm{mmol})$ and $\mathrm{NEt}_{3}$ in dry DCM $(15 \mathrm{ml})$. The mixture was stirred for $30 \mathrm{~min}$ and was then washed with water $(2 \times 5 \mathrm{ml})$, dried over $\mathrm{MgSO}_{4}$ and evaporated to dryness as quickly as possible. The residue was triturated with dry THF $(3 \times 5 \mathrm{ml})$, then dry diethyl ether $(2 \times 10 \mathrm{ml})$. Drying under vacuum at $80{ }^{\circ} \mathrm{C}$ for 3 days (which were required for fully removing all of the solvent from the solid) led to a pale yellow coloring of the compound (349 mg, $72 \%)$. ${ }^{1} \mathrm{H}$ NMR $\left(500.13 \mathrm{MHz}, \mathrm{CDCl}_{3}\right): 7.86$ (dd, $\left.{ }^{3} J_{\mathrm{HH}}=7.3 \mathrm{~Hz},{ }^{3} J_{\mathrm{HH}}=1.5 \mathrm{~Hz}, 4 \mathrm{H}, \mathrm{C}^{\text {benz. }} \mathrm{C}^{\text {quart. }} \mathrm{C}^{\mathrm{Ar}} H\right), 7.45-7.34(\mathrm{~m}$, $\left.12 \mathrm{H}, \mathrm{C}^{\mathrm{Ar}} H\right), 7.14$ (s, 2H, $\left.\mathrm{C}^{\text {benz }} H\right), 6.82(\mathrm{~s}, 1 \mathrm{H}, \mathrm{NC} H \mathrm{~N}), 6.75$ (s, $2 \mathrm{H}$, $\left.\mathrm{C}^{\text {olef. }} H\right), 6.39\left(\mathrm{~d},{ }^{4} J_{\mathrm{H}, \mathrm{H}}=1.7 \mathrm{~Hz}, 2 \mathrm{H}, \mathrm{C} H^{\mathrm{Imi}}\right) .{ }^{13} \mathrm{C}\left\{{ }^{1} \mathrm{H}\right\}$ DEPTQ NMR

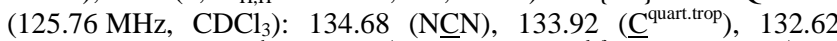
$\left(\underline{\mathrm{C}}^{\text {quart.trop }}\right), 131.47\left(\mathrm{C}^{\text {benz. }} \mathrm{C}^{\text {quart. }} \underline{C}^{\mathrm{Ar}} \mathrm{H}\right), 130.50\left(\underline{\mathrm{C}}^{\text {olef. }} H\right), 130.16\left(\underline{\mathrm{C}}^{\mathrm{Ar}} \mathrm{H}\right)$, $130.04\left(\underline{\mathrm{C}}^{\mathrm{Ar}} \mathrm{H}\right), 129.72\left(\underline{\mathrm{C}}^{\mathrm{Ar}} \mathrm{H}\right), 120.98\left(\mathrm{~s}, \underline{\mathrm{C}}^{\mathrm{Im}} \mathrm{H}\right), 68.40\left(\underline{\mathrm{C}}^{\mathrm{benz}} \mathrm{H}\right) . \mathrm{CS}$ (ESI $\left.{ }^{+}, \mathrm{MeCN}\right)$ : Calcd.: $449.20\left(\mathrm{M}-\mathrm{Cl}^{+}\right), 191.09$ (dibenzotropylium cation); Found: 449.19, 191.09.

Preparation of "[(Me-NHC-Trop)AuCl]" (Me-2). Me-1 (61.7 mg, $200 \mu \mathrm{mol})$, [(DMS)AuCl] $(58.9 \mathrm{mg}, 200 \mu \mathrm{mol})$ and $\mathrm{K}_{2} \mathrm{CO}_{3}(55.3 \mathrm{mg}$, $400 \mu \mathrm{mol})$ were suspended in dry acetone $(3 \mathrm{ml})$ and were stirred at
$60{ }^{\circ} \mathrm{C}$ for $4 \mathrm{~h}$. The mixture was filtered through a pad of Celite (glas pipette: $1 / 3$ filled) and the filtrate was evaporated to dryness on a rotary evaporator. After filtering the crude product quickly through a pad of silica gel (glass pipette: 1/3 filled) and rinsing the pad with dichloromethane $(3 \times 1.5 \mathrm{ml})$ the filtrate was reduced to approximately $1 \mathrm{ml}$ and the product was precipitated by slow addition of pentane under vigorous stirring. After decanting the mother liquor the precipitate was wahed with pentane $(2 \times 2 \mathrm{ml})$ and then dried under vacuum to give Me-2 as a microcrystalline white solid (61.7 mg, $61 \%$ yield). Single crystals suitable for X-ray diffraction analysis were obtained by slow vapor diffusion of pentane into a solution of $\mathbf{M e - 2}$ in $\mathrm{CHCl}_{3}$. Anal. Calcd. for $\mathrm{C}_{19} \mathrm{H}_{16} \mathrm{AuClN}_{2}$ (504.76 g/mol): C, 45.21; H, 3.19; N, $5.55 \%$. Found: C, 45.20; H, 3.36; N, $5.38 \%$. ${ }^{1} \mathrm{H}$ NMR $(400.13 \mathrm{MHz}$, $\mathrm{CDCl}_{3}$ ): 7.81 (ps.d, ${ }^{3} \mathrm{~J}_{\mathrm{HH}}=7.3 \mathrm{~Hz}, 2 \mathrm{H}, \mathrm{C}^{\text {benz. }} \mathrm{C}^{\text {quart. }} \mathrm{C}^{\mathrm{Ar}} H$ ), $7.53-7.47$ $\left(\mathrm{m}, 2 \mathrm{H}, \mathrm{C}^{\mathrm{Ar}} H\right), 7.46-7.43\left(\mathrm{~m}, 4 \mathrm{H}, \mathrm{C}^{\mathrm{Ar}} H\right), 6.95$ (s, 2H, $\left.\mathrm{C}^{\text {olef. }} H\right), 6.78$ $\left(\mathrm{s}, 1 \mathrm{H}, \mathrm{C}^{\text {benz. }} H\right), 6.62\left(\mathrm{~d},{ }^{3} J_{\mathrm{H}, \mathrm{H}}=2.0 \mathrm{~Hz}, 1 \mathrm{H}, \mathrm{MeNC} H \mathrm{CHN}\right), 6.58(\mathrm{~d}$, $\left.{ }^{3} J_{\mathrm{HH}}=2.0 \mathrm{~Hz}, 1 \mathrm{H}, \operatorname{MeNCHC} H \mathrm{~N}\right), 3.68(\mathrm{~s}, 3 \mathrm{H}, M e \mathrm{~N}),{ }^{13} \mathrm{C}\left\{{ }^{1} \mathrm{H}\right\}$ DEPTQ NMR (100.61 MHz, $\left.\mathrm{CDCl}_{3}\right): 171.02(\mathrm{NCN}), \quad 134.55$ $\left(\underline{C}^{\text {quart.trop }}\right), \quad 134.40 \quad\left(\underline{C}^{\text {quart.trop }}\right), \quad 131.57 \quad\left(\mathrm{C}^{\text {benz. }} \mathrm{C}^{\text {quart. }} C^{\mathrm{Ar}} \mathrm{H}\right), \quad 131.07$ $\left(\mathrm{C}^{\text {olef. }} H\right), 130.47\left(\mathrm{C}^{\mathrm{Ar}} \mathrm{H}\right), 129.93\left(\mathrm{C}^{\mathrm{Ar}} \mathrm{H}\right), 129.19\left(\mathrm{C}^{\mathrm{Ar}} \mathrm{H}\right), 120.96(\mathrm{~s}$, MeNCHCHN), 120.00 (s, MeNCHCHN), 70.84 ( $\left.\underline{C}^{\text {benz. }} \mathrm{H}\right) 38.93$ $\left(\left(\mathrm{H}_{3} \underline{\mathrm{C}}\right) \mathrm{N}\right)$.

Preparation of "[(DiPP-NHC-Trop $) \mathrm{AuCl}]$ " (DiPP-2). DiPP-1 $(91.0 \mathrm{mg}, 200 \mu \mathrm{mol}),[(\mathrm{DMS}) \mathrm{AuCl}](58.9 \mathrm{mg}, 200 \mu \mathrm{mol})$ and $\mathrm{K}_{2} \mathrm{CO}_{3}$ $(55.3 \mathrm{mg}, 400 \mu \mathrm{mol})$ were suspended in dry acetone $(3 \mathrm{ml})$ and were stirred at $60{ }^{\circ} \mathrm{C}$ for $7 \mathrm{~h}$. The mixture was filtered through a pad of silica (glas pipette: $1 / 3$ filled) and the filtrate was evaporated to dryness on a rotary evaporator. After filtering the crude product through a pad of silica gel (glass pipette: $1 / 3$ filled) and rinsing the pad with dichloromethane $(3 \times 1.5 \mathrm{ml})$ the filtrate was evaporated to dryness. Slow vapor diffusion of pentane $(2.5 \mathrm{ml})$ into a solution of the crude product in $\mathrm{CHCl}_{3}$ provided DiPP-2 as colorless plates $(80 \mathrm{mg}, 68 \%$ yield) which were suitable for X-ray diffraction analysis Anal. Calcd. for $\mathrm{C}_{30} \mathrm{H}_{30} \mathrm{AuClN}_{2}(651.00 \mathrm{~g} / \mathrm{mol}): \mathrm{C}, 55.35 ; \mathrm{H}, 4.64 ; \mathrm{N}, 4.30 \%$. Found: C, 55.23; H, 4.62; N, 4.36\%. ${ }^{1} \mathrm{H}$ NMR $\left(500.13 \mathrm{MHz}, \mathrm{CDCl}_{3}\right)$ : 7.83 (ps.d, $\left.J_{\mathrm{HH}}=7.5 \mathrm{~Hz}, 2 \mathrm{H}, \mathrm{C}^{\text {benz. }} \mathrm{C}^{\text {quart. }} \mathrm{C}^{\mathrm{Ar}} H\right), 7.56-7.51(\mathrm{~m}, 2 \mathrm{H}$, $\left.\mathrm{C}^{\mathrm{Ar}} H\right), 7.50-7.47\left(\mathrm{~m}, 4 \mathrm{H}, \mathrm{C}^{\mathrm{Ar}} H\right), 7.37\left(\mathrm{t},{ }^{3} J_{\mathrm{HH}}=7.8 \mathrm{~Hz}, 1 \mathrm{H}, p-\right.$ $\left.\mathrm{C}^{\text {DiPP }} \mathrm{H}\right), 7.14\left(\mathrm{~d},{ }^{3} J_{\mathrm{HH}}=7.8 \mathrm{~Hz}, 2 \mathrm{H}, m-\mathrm{C}^{\mathrm{DiPP}} \mathrm{H}\right), 6.97\left(\mathrm{~s}, 2 \mathrm{H}, \mathrm{C}^{\text {ole. }} H\right)$, $6.78\left(\mathrm{~s}, 1 \mathrm{H}, \mathrm{C}^{\text {benz. }} H\right), 6.63\left(\mathrm{~d},{ }^{3} J_{\mathrm{H}, \mathrm{H}}=2.0 \mathrm{~Hz}, 1 \mathrm{H}, \mathrm{C}^{\mathrm{Imi}} H\right), 6.61\left(\mathrm{~d},{ }^{3} J_{\mathrm{H}, \mathrm{H}}\right.$ $\left.=2.0 \mathrm{~Hz}, 1 \mathrm{H}, \mathrm{C}^{\mathrm{Imi}} H\right), 2.23\left(\mathrm{sept},{ }^{3} J_{\mathrm{HH}}=6.9 \mathrm{~Hz}, 2 \mathrm{H}, \mathrm{CH}\left(\mathrm{CH}_{3}\right)_{2}\right), 1.17$ $\left(\mathrm{d},{ }^{3} J_{\mathrm{HH}}=6.8 \mathrm{~Hz}, 6 \mathrm{H}, 2 \times \mathrm{CH}\left(\mathrm{CH}_{3}\right)^{\mathrm{a}}\left(\mathrm{CH}_{3}\right)^{\mathrm{b}}\right), 1.04\left(\mathrm{~d},{ }^{3} J_{\mathrm{HH}}=6.9 \mathrm{~Hz}\right.$, $\left.6 \mathrm{H}, 2 \times \mathrm{CH}\left(\mathrm{CH}_{3}\right)^{\mathrm{a}}\left(\mathrm{CH}_{3}\right)^{\mathrm{b}}\right) .{ }^{13} \mathrm{C}\left\{{ }^{1} \mathrm{H}\right\}$ DEPTQ NMR $(125.76 \mathrm{MHz}$, $\left.\mathrm{CDCl}_{3}\right): 173.43(\mathrm{NCN}), 145.53\left(\underline{\mathrm{C}}^{\mathrm{DiPP}}-\mathrm{N}\right), 134.94\left(\underline{\mathrm{C}}^{\text {quart.trop }}+o-\mathrm{C}^{\mathrm{DiPP}}\right)$, 134.32 ( $\left.\mathrm{C}^{\text {quart.trop }}\right), 131.21\left(\mathrm{C}^{\text {benz }} \mathrm{C}^{\text {quart. }} C^{\mathrm{Ar}} \mathrm{H}\right), 130.79\left(\mathrm{C}^{\text {olef. }} H\right), 130.44$ $\left(p-C^{\mathrm{DiPP}} \mathrm{H}\right), 130.27\left(\underline{\mathrm{C}}^{\mathrm{Ar}} \mathrm{H}\right), 129.93\left(\underline{\mathrm{C}}^{\mathrm{Ar}} \mathrm{H}\right), 129.20\left(\underline{\mathrm{C}}^{\mathrm{Ar}} \mathrm{H}\right), 124.14(\mathrm{~m}-$ $\left.\underline{\mathrm{C}}^{\mathrm{DiPP}} \mathrm{H}\right), 121.11\left(\mathrm{~s}, \underline{\mathrm{C}}^{\mathrm{Imi}} \mathrm{H}\right), 120.96\left(\mathrm{~s}, \underline{\mathrm{C}}^{\mathrm{Imi}} \mathrm{H}\right), 70.60\left(\underline{\mathrm{C}}^{\text {benz. }} \mathrm{H}\right), 28.33$ $\left(\underline{\mathrm{CH}}\left(\mathrm{CH}_{3}\right)_{2}\right), 24.40\left(\overline{\mathrm{CH}}\left(\mathrm{CH}_{3}\right)^{\mathrm{a}}\left(\mathrm{CH}_{3}\right)^{\mathrm{b}}\right), 24.29\left(\mathrm{CH}\left(\mathrm{CH}_{3}\right)^{\mathrm{a}}\left(\underline{\mathrm{CH}}_{3}\right)^{\mathrm{b}}\right)$.

Preparation of "[(Ad-NHC-Trop)AuCl]" (Ad-2). Ad-1 (85.8 mg, $200 \mu \mathrm{mol}),[(\mathrm{DMS}) \mathrm{AuCl}](58.9 \mathrm{mg}, 200 \mu \mathrm{mol})$ and $\mathrm{K}_{2} \mathrm{CO}_{3}(55.3 \mathrm{mg}$, $400 \mu \mathrm{mol})$ were suspended in dry acetone $(3 \mathrm{ml})$ and were stirred at $60{ }^{\circ} \mathrm{C}$ for $7 \mathrm{~h}$. The mixture was filtered through a pad of Celite (glass pipette: $1 / 3$ filled) and the filtrate was evaporated to dryness on a rotary evaporator. After filtering the crude product quickly through a pad of silica gel (glass pipette: 1/3 filled) and rinsing the pad with dichloromethane $(3 \times 1.5 \mathrm{ml})$ the filtrate was evaporated to dryness. Trituration of the residue with pentane $(2 \times 2 \mathrm{ml})$ and drying under vacuum gave Ad-2 as a white solid ( $85 \mathrm{mg}, 68 \%$ yield). Anal. Calcd. for $\mathrm{C}_{28} \mathrm{H}_{28} \mathrm{AuClN}_{2}(624.96 \mathrm{~g} / \mathrm{mol}): \mathrm{C}, 53.81 ; \mathrm{H}, 4.52 ; \mathrm{N}, 4.48 \%$. Found: C, 53.68; H, 4.61; N, 4.51\%. ${ }^{1} \mathrm{H}$ NMR $\left(300.06 \mathrm{MHz}, \mathrm{CDCl}_{3}\right)$ : 7.90 (ps.d, $\left.J_{\mathrm{HH}}=7.3 \mathrm{~Hz}, 2 \mathrm{H}, \mathrm{C}^{\text {benz. }} \mathrm{C}^{\text {quart. }} \mathrm{C}^{\mathrm{Ar}} H\right), 7.52-7.44(\mathrm{~m}, 2 \mathrm{H}$, $\left.\mathrm{C}^{\mathrm{Ar}} H\right), 7.44-7.41\left(\mathrm{~m}, 4 \mathrm{H}, \mathrm{C}^{\mathrm{Ar}} H\right), 7.15$ (s, $\left.1 \mathrm{H}, \mathrm{C}^{\text {benz. }} H\right), 6.97$ (s, $2 \mathrm{H}$, $\left.\mathrm{C}^{\text {olef. }} H\right), 6.79\left(\mathrm{~d},{ }^{3} J_{\mathrm{H}, \mathrm{H}}=2.2 \mathrm{~Hz}, 1 \mathrm{H}, \mathrm{C}^{\mathrm{Imi}} H\right), 6.74\left(\mathrm{~d},{ }^{3} J_{\mathrm{H}, \mathrm{H}}=2.0 \mathrm{~Hz}\right.$, $\left.1 \mathrm{H}, \mathrm{C}^{\mathrm{Imi}} H\right), 2.39\left(\mathrm{~d},{ }^{3} J_{\mathrm{HH}}=3.1 \mathrm{~Hz}, 6 \mathrm{H}, \mathrm{C}^{\mathrm{Ad}} H_{2}\right), 2.18\left(\mathrm{~s}, \mathrm{C}^{\mathrm{Ad}} H\right), 1.69$ $\left(\mathrm{t}, J_{\mathrm{HH}}=2.9 \mathrm{~Hz}, 6 \mathrm{H}, \mathrm{C}^{\mathrm{Ad}} H_{2}\right) .{ }^{13} \mathrm{C}\left\{{ }^{1} \mathrm{H}\right\}$ DEPTQ NMR $(75.45 \mathrm{MHz}$, $\left.\mathrm{CDCl}_{3}\right): 168.11(\mathrm{NCN}), 134.83\left(\underline{C}^{\text {quart.trop }}\right), 134.48\left(\underline{C}^{\text {quart.trop }}\right), 132.99$ $\left(\mathrm{C}^{\text {benz. }} \mathrm{C}^{\text {quart }} \underline{C}^{\mathrm{Ar}} \mathrm{H}\right), 131.27\left(\mathrm{C}^{\text {olef. }} H\right), 130.57\left(\underline{\mathrm{C}}^{\mathrm{Ar}} \mathrm{H}\right), 129.93\left(\underline{\mathrm{C}}^{\mathrm{Ar}} \mathrm{H}\right)$, $129.06\left(\mathrm{C}^{\mathrm{A}^{\mathrm{r}}} \mathrm{H}\right), 118.68\left(\mathrm{~s}, \underline{\mathrm{C}}^{\mathrm{Imi}} \mathrm{H}\right), 116.42\left(\mathrm{~s}, \underline{\mathrm{C}}^{\mathrm{Imi}} \mathrm{H}\right), 72.26\left(\underline{\mathrm{C}}^{\mathrm{benz}} \mathrm{H}\right)$, $59.41\left(\underline{\mathrm{C}}^{\text {quart. }}-\mathrm{N}\right), 44.21\left(\underline{\mathrm{C}}^{\mathrm{Ad}} \mathrm{H}_{2}\right), 35.84\left(\underline{\mathrm{C}}^{\mathrm{Ad}} \mathrm{H}_{2}\right), 29.93\left(\underline{\mathrm{C}}^{\mathrm{Ad}} \mathrm{H}\right)$. 
Preparation of “(Trop-NHC-Trop) $\mathrm{AuCl}$ " (Trop-2). Trop-1 $(91.0 \mathrm{mg}, 200 \mu \mathrm{mol})$, [(DMS)AuCl] $(58.9 \mathrm{mg}, 200 \mu \mathrm{mol})$ and $\mathrm{K}_{2} \mathrm{CO}_{3}$ $(55.3 \mathrm{mg}, 400 \mu \mathrm{mol})$ were suspended in dry acetone $(3 \mathrm{ml})$ and were stirred at $60{ }^{\circ} \mathrm{C}$ for $7 \mathrm{~h}$. The mixture was filtered through a pad of Celite (glass pipette: $1 / 3$ filled) and the filtrate was evaporated to dryness on a rotary evaporator. After filtering the crude product through a pad of silica gel (glass pipette: $1 / 3$ filled) and rinsing the pad with dichloromethane $(3 \times 1.5 \mathrm{ml})$, the solvent was removed and the product was triturated with pentane $(2 \times 2 \mathrm{ml})$. A white powder is obtained after drying under vacuum ( $83 \mathrm{mg}, 65 \%$ yield). Colorless needles of Trop-1 suitable for X-ray diffraction analysis were grown by slow vapor diffusion of pentane into a concentrated solution of the compound in $\mathrm{CHCl}_{3}$. Anal. Calcd. for $\mathrm{C}_{33} \mathrm{H}_{24} \mathrm{AuClN}_{2}(680.99 \mathrm{~g} / \mathrm{mol})$ : C, 58.20; H, 3.55; N, 4.11\%. Found: C, 58.05; H, 3.49; N, 4.02\%. ${ }^{1} \mathrm{H}$ $\operatorname{NMR}\left(500.13 \mathrm{MHz}, \mathrm{CDCl}_{3}\right): 7.75$ (ps.d, $J_{\mathrm{HH}}=7.4 \mathrm{~Hz}, 4 \mathrm{H}$, $\left.\mathrm{C}^{\text {benz. }} \mathrm{C}^{\text {quart. }} \mathrm{C}^{\mathrm{Ar}} H\right), 7.43\left(\mathrm{dt}, J=10.8 \mathrm{~Hz}, J=1.9 \mathrm{~Hz}, 4 \mathrm{H}, \mathrm{C}^{\mathrm{Ar}} H\right), 7.40-$ $7.35\left(\mathrm{~m}, 8 \mathrm{H}, \mathrm{C}^{\mathrm{Ar}} H\right), 6.86\left(\mathrm{~s}, 4 \mathrm{H}, \mathrm{C}^{\text {olef. }} H\right), 6.82\left(\mathrm{~d},{ }^{3} J_{\mathrm{H}, \mathrm{H}}=2.2 \mathrm{~Hz}, 2 \mathrm{H}\right.$, $\mathrm{C}^{\text {benz. }} H$ ), 6.39 (s, $\left.2 \mathrm{H}, \mathrm{C}^{\mathrm{Imi}} H\right) .{ }^{13} \mathrm{C}\left\{{ }^{1} \mathrm{H}\right\}$ DEPTQ NMR $(125.76 \mathrm{MHz}$, $\left.\mathrm{CDCl}_{3}\right): 169.68(\mathrm{~N} \underline{\mathrm{CN}}), 134.48\left(\underline{\mathrm{C}}^{\text {quart.trop }}\right), 134.39\left(\underline{\mathrm{C}}^{\text {quart.trop }}\right), 131.80$ $\left(\mathrm{C}^{\text {benz. }} \mathrm{C}^{\text {quart. }} \underline{C}^{\mathrm{Ar}} \mathrm{H}\right), 131.13\left(\underline{\mathrm{C}}^{\text {olef. }} H\right), 130.43\left(\underline{\mathrm{C}}^{\mathrm{Ar}} \mathrm{H}\right), 129.85\left(\underline{\mathrm{C}}^{\mathrm{Ar}} \mathrm{H}\right)$, $129.05\left(\underline{\mathrm{C}}^{\mathrm{Ar}} \mathrm{H}\right), 119.31\left(\mathrm{~s}, \underline{\mathrm{C}}^{\mathrm{Imi}} \mathrm{H}\right), 71.29\left(\underline{\mathrm{C}}^{\text {benz. }} \mathrm{H}\right)$.

Preparation of "[(Me-NHC-Trop) $\left.\mathrm{Au}\left(\mathrm{NTf}_{2}\right)\right]$ " (Me-3). Gold complex Me-2 $(25.2 \mathrm{mg}, 50.0 \mu \mathrm{mol})$ and $\operatorname{AgNTf}_{2}(23.3 \mathrm{mg}, 60.0 \mu \mathrm{mol})$ were dried under vacuum for $15 \mathrm{~min}$. Under an atmosphere of argon, dry dichloromethane $(3 \mathrm{ml})$ was added and the mixture was stirred in the dark for $10 \mathrm{~min}$. The suspension was filtered through a pad of Celite (glass pipette: $1 / 3$ filled), which was subsequently rinsed with dichloromethane $(3 \times 1 \mathrm{ml})$ and the filtrate was concentrated to approx. $0.2 \mathrm{ml}$. After the addition of pentane $(2 \mathrm{ml})$ the product slowly precipitated as a microcrystalline material which was further washed with pentane $(2 \times 1 \mathrm{ml})$. The product was obtained as a white solid after drying under vacuum (33 mg, $88 \%$ yield). Single crystals suitable for X-ray diffraction analysis were obtained by slow vapor diffusion of pentane into a solution of $\mathbf{M e}-3$ in $\mathrm{CHCl}_{3}$. Anal. Calcd. for $\mathrm{C}_{21} \mathrm{H}_{16} \mathrm{AuF}_{6} \mathrm{~N}_{3} \mathrm{O}_{4} \mathrm{~S}_{2}(749.45 \mathrm{~g} / \mathrm{mol}): \mathrm{C}, 33.66 ; \mathrm{H}, 2.15 ; \mathrm{N}, 5.61 \%$. Found: C, 33.74; H, 1.97; N, $5.68 \% .{ }^{1} \mathrm{H}$ NMR $\left(500.13 \mathrm{MHz}, \mathrm{CDCl}_{3}\right)$ : 7.81 (ps.d, $\left.{ }^{3} J_{\mathrm{HH}}=7.4 \mathrm{~Hz}, 2 \mathrm{H}, \mathrm{C}^{\text {benz. }} \mathrm{C}^{\text {quart. }} \mathrm{C}^{\mathrm{Ar}} H\right), 7.54-7.49(\mathrm{~m}, 2 \mathrm{H}$, $\left.\mathrm{C}^{\mathrm{Ar}} H\right), 7.48-7.44\left(\mathrm{~m}, 4 \mathrm{H}, \mathrm{C}^{\mathrm{Ar}} H\right), 6.98\left(\mathrm{~s}, 2 \mathrm{H}, \mathrm{C}^{\text {olef. }} H\right), 6.77(\mathrm{~s}, 1 \mathrm{H}$, $\left.\mathrm{C}^{\text {benz. }} H\right), 6.70\left(\mathrm{~d},{ }^{3} J_{\mathrm{H}, \mathrm{H}}=2.1 \mathrm{~Hz}, 1 \mathrm{H}, \mathrm{MeNCHCHN}\right), 6.68\left(\mathrm{~d},{ }^{3} J_{\mathrm{HH}}=\right.$ $2.1 \mathrm{~Hz}, 1 \mathrm{H}, \mathrm{MeNCHCHN}), 3.71(\mathrm{~s}, 3 \mathrm{H}, \mathrm{MeN}) .{ }^{13} \mathrm{C}\left\{{ }^{1} \mathrm{H}\right\}$ DEPTQ NMR $\left(125.76 \mathrm{MHz}, \mathrm{CDCl}_{3}\right): 163.27(\mathrm{NCN}), 134.37$ (C $\left.\underline{C}^{\text {quart.trop }}\right)$ 134.11 ( $\left.\underline{\mathrm{C}}^{\text {quart.trop }}\right), 131.66\left(\mathrm{C}^{\text {benz }} \mathrm{C}^{\text {quart. }}{ }^{\mathrm{C}}{ }^{\mathrm{Ar}} \mathrm{H}\right), 131.21\left(\underline{\mathrm{C}}^{\text {olef. }} H\right), 130.65$ $\left(\underline{\mathrm{C}}^{\mathrm{Ar}} \mathrm{H}\right), 130.10\left(\underline{\mathrm{C}}^{\mathrm{Ar}} \mathrm{H}\right), 129.42\left(\underline{\mathrm{C}}^{\mathrm{Ar}} \mathrm{H}\right), 121.77$ (s, MeNCHCHN), 120.67 (s, MeNCHCHN), 119.56 (q, $\left.{ }^{1} J_{\mathrm{CF}}=321.1 \mathrm{~Hz}, \underline{\mathrm{CF}}_{3}\right), 71.54$ $\left(\underline{\mathrm{C}}^{\text {benz. }} \mathrm{H}\right) 39.09\left(\left(\mathrm{H}_{3} \mathrm{C}\right) \mathrm{N}\right)$.

Preparation of "[(DiPP-NHC-Trop)Au(NTf 2$)]$ " (DiPP-3). Gold complex DiPP-2 $(35.0 \mathrm{mg}, 53.8 \mu \mathrm{mol})$ and $\mathrm{AgNTf}_{2}(20.9 \mathrm{mg}$, $53.8 \mu \mathrm{mol})$ were dried under vacuum for $10 \mathrm{~min}$. Under an atmosphere of argon, dichloromethane $(3 \mathrm{ml})$ was quickly added and the mixture was stirred in the dark for $20 \mathrm{~min}$. The suspension was filtered through a pad of Celite (glass pipette: $1 / 3$ filled), which was subsequently rinsed with dichloromethane $(3 \times 1 \mathrm{ml})$ and the filtrate was concentrated to approx. $0.3 \mathrm{ml}$. The slow addition of pentane $(\sim 2$ $\mathrm{ml}$ ) led to the precipitation of the product as colorless needles which were further washed with pentane $(2 \times 1 \mathrm{ml})$ and dried under vacuum (41 mg, 85\% yield). Single crystals suitable for X-ray diffraction analysis were obtained by slow vapor diffusion of pentane into a solution of DiPP-3 in $\mathrm{CHCl}_{3}$. Anal. Calcd. for $\mathrm{C}_{32} \mathrm{H}_{30} \mathrm{AuF}_{6} \mathrm{~N}_{3} \mathrm{O}_{4} \mathrm{~S}_{2}$ (895.68 g/mol): C, 42.91; H, 3.38; N, 4.69\%. Found: C, 43.02; H, $3.41 ; \mathrm{N}, 4.75 \%$. ${ }^{1} \mathrm{H}$ NMR $\left(500.13 \mathrm{MHz}, \mathrm{CDCl}_{3}\right): 7.81$ (ps.d, $J_{\mathrm{HH}}=$ $\left.7.6 \mathrm{~Hz}, 2 \mathrm{H}, \mathrm{C}^{\text {benz. }} \mathrm{C}^{\text {quart. }} \mathrm{C}^{\mathrm{Ar}} H\right), 7.57-7.52\left(\mathrm{~m}, 2 \mathrm{H}, \mathrm{C}^{\mathrm{Ar}} H\right), 7.51-7.47$ $\left(\mathrm{m}, 4 \mathrm{H}, \mathrm{C}^{\mathrm{Ar}} H\right), 7.42\left(\mathrm{t},{ }^{3} J_{\mathrm{HH}}=7.8 \mathrm{~Hz}, 1 \mathrm{H}, p-\mathrm{C}^{\mathrm{DiPP}} \mathrm{H}\right), 7.18\left(\mathrm{~d},{ }^{3} J_{\mathrm{HH}}=\right.$ $\left.7.6 \mathrm{~Hz}, 2 \mathrm{H}, m-\mathrm{C}^{\mathrm{DiPP}} \mathrm{H}\right), 6.96\left(\mathrm{~s}, 2 \mathrm{H}, \mathrm{C}^{\text {olef. }} H\right), 6.73\left(\mathrm{~d},{ }^{3} J_{\mathrm{H}, \mathrm{H}}=2.0 \mathrm{~Hz}\right.$, $\left.1 \mathrm{H}, \mathrm{C}^{\mathrm{Imi}} H\right), 6.72\left(\mathrm{~s}, 1 \mathrm{H}, \mathrm{C}^{\text {benz. }} H\right), 6.63\left(\mathrm{~d},{ }^{3} J_{\mathrm{H}, \mathrm{H}}=2.0 \mathrm{~Hz}, 1 \mathrm{H}, \mathrm{C}^{\mathrm{Imi}} H\right)$, $2.17\left(\mathrm{sept},{ }^{3} J_{\mathrm{HH}}=6.9 \mathrm{~Hz}, 2 \mathrm{H}, \mathrm{CH}\left(\mathrm{CH}_{3}\right)_{2}\right), 1.14\left(\mathrm{~d},{ }^{3} J_{\mathrm{HH}}=6.5 \mathrm{~Hz}, 6 \mathrm{H}\right.$, $\left.2 \times \mathrm{CH}\left(\mathrm{CH}_{3}\right)^{\mathrm{a}}\left(\mathrm{CH}_{3}\right)^{\mathrm{b}}\right), \quad 1.04\left(\mathrm{~d},{ }^{3} J_{\mathrm{HH}}=6.9 \mathrm{~Hz}, 6 \mathrm{H}, 2 \times\right.$ $\left.\mathrm{CH}\left(\mathrm{CH}_{3}\right)^{\mathrm{a}}\left(\mathrm{CH}_{3}\right)^{\mathrm{b}}\right) .{ }^{13} \mathrm{C}\left\{{ }^{1} \mathrm{H}\right\}$ DEPTQ NMR $\left(125.76 \mathrm{MHz}, \mathrm{CDCl}_{3}\right)$ : $166.28(\mathrm{NCN}), \quad 145.45 \quad\left(\underline{C}^{\mathrm{DiPP}}-\mathrm{N}\right), \quad 134.62 \quad\left(o-\underline{C}^{\mathrm{DiPP}} \mathrm{H}\right), \quad 134.56$ $\left(\underline{\mathrm{C}}^{\text {quart.trop }}\right), \quad 134.17 \quad\left(\underline{\mathrm{C}}^{\text {quart.trop }}\right), \quad 131.13 \quad\left(\mathrm{C}^{\text {benz. }} \mathrm{C}^{\text {quart. }} \underline{C}^{\mathrm{Ar}} \mathrm{H}\right), \quad 130.77$ $\left(\underline{\mathrm{C}}^{\text {olef. }} H\right), 130.64\left(p-\underline{\mathrm{C}}^{\mathrm{DiPP}} \mathrm{H}\right), 130.38\left(\underline{\mathrm{C}}^{\mathrm{Ar}} \mathrm{H}\right), 129.97\left(\underline{\mathrm{C}}^{\mathrm{Ar}} \mathrm{H}\right), 129.41$
$\left(\underline{C}^{\mathrm{Ar}} \mathrm{H}\right), 124.14\left(m-\underline{\mathrm{C}}^{\mathrm{DiPP}} \mathrm{H}\right), 121.78\left(\mathrm{~s}, \mathrm{C}^{\mathrm{Imi}} \mathrm{H}\right), 121.50\left(\mathrm{~s}, \mathrm{C}^{\mathrm{Imi}} \mathrm{H}\right)$, $119.21\left(\mathrm{q},{ }^{1} J_{\mathrm{CF}}=323.2 \mathrm{~Hz}, \underline{\mathrm{CF}}_{3}\right), 70.78\left(\underline{\mathrm{C}}^{\mathrm{benz}} \mathrm{H}\right), 28.41\left(\underline{\mathrm{CH}}\left(\mathrm{CH}_{3}\right)_{2}\right)$, $24.62\left(\mathrm{CH}\left(\mathrm{CH}_{3}\right)^{\mathrm{a}}\left(\mathrm{CH}_{3}\right)^{\mathrm{b}}\right), 24.58\left(\mathrm{CH}\left(\mathrm{CH}_{3}\right)^{\mathrm{a}}\left(\mathrm{CH}_{3}\right)^{\mathrm{b}}\right)$.

Preparation of "[(Ad-NHC-Trop)Au(NTf $)]$ " (Ad-3). Gold complex Ad-2 $(25.0 \mathrm{mg}, 40.0 \mu \mathrm{mol})$ and $\operatorname{AgNTf}_{2}(15.5 \mathrm{mg}, 40.0 \mu \mathrm{mol})$ were dried under vacuum for $10 \mathrm{~min}$. Under an atmosphere of argon, dichloromethane $(2 \mathrm{ml})$ was quickly added and the mixture was stirred in the dark for $10 \mathrm{~min}$. The suspension was filtered through a pad of Celite (glass pipette: $1 / 3$ filled), which was subsequently rinsed with dichloromethane $(3 \times 1 \mathrm{ml})$ and the filtrate was evaporated to dryness. The crude product was filtered once again through Celite and was concentrated to approx. $0.5 \mathrm{ml}$. The product was precipitated by the addition of pentane $(\sim 3 \mathrm{ml})$, washed with pentane $(2 \mathrm{ml})$ and dried under vacuum (32 mg, 92\% yield). Single crystals suitable for $\mathrm{X}$-ray diffraction analysis were obtained by slow vapor diffusion of pentane into a solution of $\mathbf{A d - 3}$ in $\mathrm{CHCl}_{3}$. Anal. Calcd. for $\mathrm{C}_{30} \mathrm{H}_{28} \mathrm{AuF}_{6} \mathrm{~N}_{3} \mathrm{O}_{4} \mathrm{~S}_{2}$ (869.65 g/mol): C, 41.43; $\mathrm{H}, 3.25 ; \mathrm{N}, 4.83 \%$. Found: C, 41.52; $\mathrm{H}, 3.34 ; \mathrm{N}, 4.86 \%$. ${ }^{1} \mathrm{H}$ NMR $\left(500.13 \mathrm{MHz}, \mathrm{CDCl}_{3}\right)$ : 7.87 (ps.d, $\left.J_{\mathrm{HH}}=7.5 \mathrm{~Hz}, 2 \mathrm{H}, \mathrm{C}^{\text {benz. }} \mathrm{C}^{\text {quart. }} \mathrm{C}^{\mathrm{Ar}} H\right), 7.52-7.47(\mathrm{~m}, 2 \mathrm{H}$, $\left.\mathrm{C}^{\mathrm{Ar}} H\right), 7.47-7.42\left(\mathrm{~m}, 4 \mathrm{H}, \mathrm{C}^{\mathrm{Ar}} H\right), 7.19\left(\mathrm{~s}, 1 \mathrm{H}, \mathrm{C}^{\text {benz. }} H\right), 7.01\left(\mathrm{~d}, J_{\mathrm{HH}}=\right.$ $\left.1.0 \mathrm{~Hz}, 2 \mathrm{H}, \mathrm{C}^{\text {olef. }} H\right), 6.99\left(\mathrm{t},{ }^{3} J_{\mathrm{H}, \mathrm{H}}=2.1 \mathrm{~Hz}, 1 \mathrm{H}, \mathrm{AdNCHCHN}\right), 6.74$ $\left(\mathrm{t},{ }^{3} J_{\mathrm{H}, \mathrm{H}}=1.7 \mathrm{~Hz}, 1 \mathrm{H}\right.$, AdNCHCHN), $2.35\left(\mathrm{~d},{ }^{3} J_{\mathrm{HH}}=2.8 \mathrm{~Hz}, 6 \mathrm{H}\right.$, $\left.\mathrm{C}^{\mathrm{Ad}} H_{2}\right), 2.22\left(\mathrm{~s}, \mathrm{C}^{\mathrm{Ad}} H\right), 1.72\left(\mathrm{t}, J_{\mathrm{HH}}=2.9 \mathrm{~Hz}, 6 \mathrm{H}, \mathrm{C}^{\mathrm{Ad}} H_{2}\right) .{ }^{13} \mathrm{C}\left\{{ }^{1} \mathrm{H}\right\}$ DEPTQ NMR (125.76 MHz, $\left.\mathrm{CDCl}_{3}\right): 159.37(\mathrm{NCN}), 134.48$ $\left(\underline{\mathrm{C}}^{\text {quart.trop }}\right), \quad 134.43 \quad\left(\mathrm{C}^{\text {quart.trop }}\right), \quad 131.90 \quad\left(\mathrm{C}^{\text {benz. }} \mathrm{C}^{\text {quart. }} \mathrm{C}^{\mathrm{Ar}} \mathrm{H}\right), \quad 131.48$ $\left(\underline{\mathrm{C}}^{\text {olef. }} H\right), 130.87\left(\underline{\mathrm{C}}^{\mathrm{Ar}} \mathrm{H}\right), 130.07\left(\underline{\mathrm{C}}^{\mathrm{Ar}} \mathrm{H}\right), 129.30\left(\underline{\mathrm{C}}^{\mathrm{Ar}} \mathrm{H}\right), 119.66(\mathrm{q}$, $\left.{ }^{1} J_{\mathrm{CF}}=323.9 \mathrm{~Hz}, \underline{\mathrm{CF}}_{3}\right), 119.14(\mathrm{~s}, \operatorname{AdNCH} \underline{\mathrm{C} H N}), 117.81(\mathrm{~s}$, AdNCHCHN), $73.31\left(\underline{C}^{\text {benz. }} H\right), 59.89\left(\underline{C}^{\text {quart }}-\mathrm{N}\right), 44.24\left(\underline{\mathrm{C}}^{\mathrm{Ad}} \mathrm{H}_{2}\right), 35.62$ $\left(\underline{\mathrm{C}}^{\mathrm{Ad}} \overline{\mathrm{H}}_{2}\right), 29.99\left(\underline{\mathrm{C}}^{\mathrm{Ad}} \mathrm{H}\right)$.

Preparation of "[(Trop-NHC-Trop $\left.) \mathrm{Au}\left(\mathrm{NTf_{2 } )}\right)\right]$ " (Trop-3). Gold complex Trop-2 $(40.9 \mathrm{mg}, 60.0 \mu \mathrm{mol})$ and $\mathrm{AgNTf}_{2}(23.3 \mathrm{mg}$, $60.0 \mu \mathrm{mol})$ were dried under vacuum for $10 \mathrm{~min}$. Under an atmosphere of argon, dichloromethane $(3 \mathrm{ml})$ was quickly added and the mixture was stirred in the dark for $20 \mathrm{~min}$. The suspension was filtered through a pad of Celite (glass pipette: 1/3 filled), which was subsequently rinsed with dichloromethane $(3 \times 1 \mathrm{ml})$ and the filtrate was concentrated to approx. $0.3 \mathrm{ml}$. The slow addition of pentane $(\sim 2$ $\mathrm{ml})$ led to the precipitation of the product as colorless needles which were further washed with pentane $(2 \times 1 \mathrm{ml})$ and dried under vacuum (40 mg, 72\% yield). Single crystals suitable for X-ray diffraction analysis were obtained by slow vapor diffusion of pentane into a solution of Trop-3 in $\mathrm{CHCl}_{3}$. Anal. Calcd. for $\mathrm{C}_{35} \mathrm{H}_{24} \mathrm{AuF}_{6} \mathrm{~N}_{3} \mathrm{O}_{4} \mathrm{~S}_{2}$ (925.67 g/mol): C, 45.41; H, 2.61; N, 4.54\%. Found: C, 45.28; H, 2.68; N, 4.58\%. ${ }^{1} \mathrm{H}$ NMR $\left(500.13 \mathrm{MHz}, \mathrm{CDCl}_{3}\right): 7.75$ (ps.d, $J_{\mathrm{HH}}=$ $\left.7.4 \mathrm{~Hz}, 4 \mathrm{H}, \mathrm{C}^{\text {benz }} \mathrm{C}^{\text {quart. }} \mathrm{C}^{\mathrm{Ar}} H\right), 7.48-7.43\left(\mathrm{~m}, 4 \mathrm{H}, \mathrm{C}^{\mathrm{Ar}} H\right), 7.43-7.36$ $\left(\mathrm{m}, 8 \mathrm{H}, \mathrm{C}^{\mathrm{Ar}} H\right), 6.88\left(\mathrm{~s}, 4 \mathrm{H}, \mathrm{C}^{\text {olef. }} H\right), 6.76\left(\mathrm{~d},{ }^{3} J_{\mathrm{H}, \mathrm{H}}=2.2 \mathrm{~Hz}, 4 \mathrm{H}\right.$, $\left.\mathrm{C}^{\text {benz. }} H\right), 6.49\left(\mathrm{~s}, 4 \mathrm{H}, \mathrm{C}^{\mathrm{Imi}} H\right) .{ }^{13} \mathrm{C}\left\{{ }^{1} \mathrm{H}\right\}$ DEPTQ NMR $(125.76 \mathrm{MHz}$, $\left.\mathrm{CDCl}_{3}\right): 161.57(\mathrm{NCN}), 134.36\left(\underline{\mathrm{C}}^{\text {quart.trop }}\right), 134.07\left(\underline{\mathrm{C}}^{\text {quart.trop }}\right), 131.83$ $\left(\mathrm{C}^{\text {benz. }} \mathrm{C}^{\text {quart. }} \underline{C}^{\mathrm{Ar}} \mathrm{H}\right), 131.23\left(\underline{\mathrm{C}}^{\text {olef. }} H\right), 130.51\left(\underline{\mathrm{C}}^{\mathrm{Ar}} \mathrm{H}\right), 129.96\left(\underline{\mathrm{C}}^{\mathrm{Ar}} \mathrm{H}\right)$, $129.26\left(\underline{C}^{\mathrm{Ar}} \mathrm{H}\right), 119.56\left(\mathrm{q},{ }^{1} J_{\mathrm{CF}}=323.9 \mathrm{~Hz}, \underline{\mathrm{CF}}_{3}\right), 120.06\left(\mathrm{~s}, \underline{\mathrm{C}}^{\mathrm{I}} \mathrm{mi}\right)$, $71.88\left(\underline{\mathrm{C}}^{\text {benz. }} \mathrm{H}\right)$.

Preparation of " $\left[(\mathrm{Me}-\mathrm{NHC}-\mathrm{Trop})_{2} \mathrm{Au}\right] \mathrm{BArF} \mathrm{F}_{24}$ " (Me-4). Solid $\mathrm{NaBArF}_{24}(15.5 \mathrm{mg}, 17.5 \mu \mathrm{mol})$ were added to a solution of Me-2 $(7.5 \mathrm{mg}, 15 \mu \mathrm{mol})$ in dry $\mathrm{CDCl}_{3}(0.6 \mathrm{ml})$ in a J. Young NMR tube. The solution was mixed by rotating the NMR tube for $90 \mathrm{~min}$ at $\sim 30$ $\mathrm{rpm}$ leading to the precipitation of a black solid. At this point in situ ${ }^{1} \mathrm{H}$ and ${ }^{19} \mathrm{~F}$ spectroscopy indicated complete conversion of the starting material to the corresponding Me-4 and $3-4$ new fluoride containing species arising likely from the decomposition of the $\mathrm{BArF}_{24}$ anion. The suspension was filtered through a pad of Celite (glass pipette, 1/3 filled) and the solvent was removed from the filtrate under vacuum. After washing the residue with pentane and drying under vacuum the product was obtained as a white solid $(11 \mathrm{mg}, 91 \%$ yield with respect to the starting quantity of ligand). Crystals suitable for X-ray diffraction analysis were obtained by slow vapor diffusion of pentane into a solution of Me-3 in $\mathrm{CHCl}_{3}$. Anal. Calcd. for $\mathrm{C}_{70} \mathrm{H}_{44} \mathrm{AuBF}_{24} \mathrm{~N}_{4}$ (1604.86 g/mol): C, 52.39; H, 2.76; N, $3.49 \%$. Found: C, 52.27; H, 2.75; N, $3.57 \% .{ }^{1} \mathrm{H}$ NMR $\left(500.13 \mathrm{MHz}, \mathrm{CDCl}_{3}\right): 7.70$ (ps.t, $J=2.2$ $\left.\mathrm{Hz}, 4 \mathrm{H}, o-\mathrm{C}^{\mathrm{BArF2} 2} \mathrm{H}\right), 7.54-7.49\left(\mathrm{~m}, 10 \mathrm{H}, 4 \mathrm{C}^{\text {benz. }} \mathrm{C}^{\text {quart. }} \mathrm{C}^{\mathrm{Ar}} \mathrm{H}+4\right.$ 
$\left.\mathrm{C}^{\text {olef. }} \mathrm{C}^{\text {quart. }} \mathrm{C}^{\mathrm{Ar}} H+2 p-\mathrm{C}^{\mathrm{BArF24}} \mathrm{H}\right), 7.40(\mathrm{dt}, J=11.3 \mathrm{~Hz}, J=1.3 \mathrm{~Hz}, 4 \mathrm{H}$, $\left.\mathrm{C}^{\mathrm{Ar}} H\right), 7.38\left(\mathrm{dt}, J=11.2 \mathrm{~Hz}, J=1.4 \mathrm{~Hz}, 4 \mathrm{H}, \mathrm{C}^{\mathrm{Ar}} H\right), 6.95(\mathrm{~s}, 4 \mathrm{H}$, $\left.\mathrm{C}^{\text {olef. }} H\right), 6.58\left(\mathrm{~d},{ }^{3} J_{\mathrm{H}, \mathrm{H}}=2.0 \mathrm{~Hz}, 2 \mathrm{H}, \mathrm{MeNCHCHN}\right), 6.27\left(\mathrm{~d},{ }^{3} J_{\mathrm{HH}}=\right.$ $2.0 \mathrm{~Hz}, 2 \mathrm{H}, \mathrm{MeNCHCHN}), 6.24$ (s, 2H, C $\left.{ }^{\text {benz. }} H\right), 3.44$ (s, 6H, MeN). ${ }^{13} \mathrm{C}\left\{{ }^{1} \mathrm{H}\right\}$ DEPTQ NMR $\left(125.76 \mathrm{MHz}, \mathrm{CDCl}_{3}\right): 184.30$ (NCN), 161.82 $\left(\mathrm{q},{ }^{1} J_{\mathrm{CB}}=49.8 \mathrm{~Hz}, \mathrm{~B}-\underline{\mathrm{C}}^{\mathrm{BArF} 24}\right), 134.93\left(o-\underline{\mathrm{C}}^{\mathrm{BArF24}}\right), 134.73\left(\underline{\mathrm{C}}^{\text {quart.trop }}\right)$, $134.60\left(\mathrm{C}^{\text {quart.trop }}\right), 130.78\left(\mathrm{C}^{\text {benz. }} \mathrm{C}^{\text {quart. }}{ }^{\mathrm{Ar}} \mathrm{H}\right), 130.58,130.39\left(\underline{\mathrm{C}}^{\text {olef. }} \mathrm{H}+\right.$ $\left.\mathrm{C}^{\text {olef. }} \mathrm{C}^{\text {quart }}{ }^{\mathrm{C}}{ }^{\mathrm{Ar}} \mathrm{H}\right), 129.28\left(\underline{\mathrm{C}}^{\mathrm{Ar}} \mathrm{H}\right), 129.16\left(\underline{\mathrm{C}}^{\mathrm{Ar}} \mathrm{H}\right), 128.9\left(\mathrm{~m}, m-\mathrm{C}^{\mathrm{BArF} 24}\right)$, $124.67\left(\mathrm{q},{ }^{1} J_{\mathrm{CF}}=272.8 \mathrm{~Hz}\right), 121.92(\mathrm{~s}, \mathrm{MeNCHCHN}), 119.78(\mathrm{~s}$, MeNCEHCHN), $117.60\left(p-\mathrm{C}^{\text {BArF24 }}\right), 70.24\left(\underline{C}^{\text {benz. }} \mathrm{H}\right) 38.98\left(\left(\mathrm{H}_{3} \underline{\mathrm{C}}\right) \mathrm{N}\right)$

Preparation of "I(DiPP-NHC-Trop $\left.)_{2} \mathrm{Au}\right] \mathrm{BArF}$ 24 $_{2}$ (DiPP-4). Solid $\mathrm{NaBArF}_{24}(15.5 \mathrm{mg}, 17.5 \mu \mathrm{mol})$ was added to a solution of DiPP-2 $(7.5 \mathrm{mg}, 15 \mu \mathrm{mol})$ in dry $\mathrm{CDCl}_{3}(0.6 \mathrm{ml})$ in a J. Young NMR tube. The solution is mixed by rotating the NMR tube over night at $\sim 30$ rpm leading to the precipitation of a black solid. In situ ${ }^{1} \mathrm{H}$ and ${ }^{19} \mathrm{~F}$ spectroscopy indicate complete conversion of the starting material to the $\mathrm{Bis}(\mathrm{NHC}) \mathrm{Au} \mathrm{BArF}_{24}$ complex and $3-4$ new fluoride containing species arising likely from the decomposition of the $\mathrm{BArF}_{24}$ anion. The suspension is filtered through a pad of Celite (glass pipette, 1/3 filled), which is subsequently rinsed with dichloromethane and the solvent is removed from the filtrate under vacuum. The residue is filtered through a pad of silica (glass pipette, 1/3 filled) using DCM. After removing the solvent from the filtrate under vacuum and washing the residue with pentane, the colorless oil was dried under vacuum which solidified over time $(18 \mathrm{mg}, 88 \%$ yield with respect to the starting quantity of ligand). Anal. Calcd. for $\mathrm{C}_{92} \mathrm{H}_{72} \mathrm{AuBF}_{24} \mathrm{~N}_{4}$ (1897.32 g/mol): C, 58.24; H, 3.82; N, $2.95 \%$. Found: C, 58.11; H, 3.76; N, $3.16 \%$. ${ }^{1} \mathrm{H}$ NMR (500.13 MHz, $\left.\mathrm{CDCl}_{3}\right)$ : 7.72 (ps.t, $J=2.2$ $\left.\mathrm{Hz}, 4 \mathrm{H}, o-\mathrm{C}^{\mathrm{BArF} 24} \mathrm{H}\right), 7.51\left(\mathrm{~s}, 2 \mathrm{H}, p-\mathrm{C}^{\mathrm{BArF} 24} \mathrm{H}\right), 7.49-7.44(\mathrm{~m}, 6 \mathrm{H}$, $\left.4 \mathrm{CArH}+2 p-\mathrm{C}^{\mathrm{DiPP}} \mathrm{H}\right), 7.41\left(\mathrm{dt}, J=11.2 \mathrm{~Hz}, J=1.2 \mathrm{~Hz}, 4 \mathrm{H}, \mathrm{C}^{\mathrm{Ar}} H\right)$, $7.32-7.28\left(\mathrm{~m}, 6 \mathrm{H}, 4 \mathrm{C}^{\mathrm{Ar}} H+2 \mathrm{DiPP}-\mathrm{NCHC} H \mathrm{~N}\right), 7.21\left(\mathrm{~d},{ }^{3} J_{\mathrm{HH}}=7.85\right.$ $\left.\mathrm{Hz}, 4 \mathrm{H}, m-\mathrm{C}^{\mathrm{DiPP}} H\right), 7.21\left(4 \mathrm{H}, \mathrm{C}^{\text {benz. }} \mathrm{C}^{\text {quart. }} \mathrm{C}^{\mathrm{Ar}} H\right.$ covered by signal of $m$ $\left.\mathrm{C}^{\text {DiPP }} H\right), 7.04\left(\mathrm{~s}, 4 \mathrm{H}, \mathrm{C}^{\text {olef. }} H\right), 6.81\left(\mathrm{~s}, 2 \mathrm{H}, \mathrm{C}^{\text {benz. }} H\right), 6.72\left(\mathrm{~d},{ }^{3} J_{\mathrm{H}, \mathrm{H}}=\right.$ $1.9 \mathrm{~Hz}, 2 \mathrm{H}$, DiPP-NCHCHN), 2.14 (sept., ${ }^{3} J_{\mathrm{HH}}=6.7 \mathrm{~Hz}, 4 \mathrm{H}$, $\left.\mathrm{CH}\left(\mathrm{CH}_{3}\right)_{2}\right), 0.95$ (ps.t., $\left.\left.J_{\mathrm{HH}}=7.1 \mathrm{~Hz}, 24 \mathrm{H}, \mathrm{CH}\left(\mathrm{CH}_{3}\right)_{2}\right)\right) .{ }^{13} \mathrm{C}\left\{{ }^{1} \mathrm{H}\right\}$ DEPTQ NMR (125.76 MHz, $\left.\mathrm{CDCl}_{3}\right): 182.90(\mathrm{NCN}), 161.84$ (q, ${ }^{1} J_{\mathrm{CB}}$ $\left.=50.0 \mathrm{~Hz}, \mathrm{~B}-\underline{\mathrm{C}}^{\mathrm{BArF24}}\right), 145.60\left(\underline{\mathrm{C}}^{\mathrm{DiPP}}-\mathrm{N}\right), 134.96\left(\mathrm{o}-\underline{\mathrm{C}}^{\mathrm{BArF} 24}\right), 134.49$ $\left(\underline{\mathrm{C}}^{\text {quart.trop }}\right), 134.32\left(\underline{\mathrm{C}}^{\text {quart.trop }}\right), 134.27\left(o-\underline{\mathrm{C}}^{\mathrm{DiPP}}\right), 131.59+131.46$ $\left(\underline{\mathrm{C}}^{\text {olef. }} \mathrm{H}+\mathrm{C}^{\text {olef. }} \overline{\mathrm{C}}^{\text {quart. }} \underline{\mathrm{C}}^{\mathrm{Ar}} \mathrm{H}\right), \quad 131.06 \quad\left(p-\underline{\mathrm{C}}^{\mathrm{DiPP}} \mathrm{H}\right), \quad 130.09$ $\left(\bar{C}^{\text {benz. }} \mathrm{C}^{\text {quart. }} \underline{C}^{\mathrm{Ar}} \mathrm{H}\right), 129.66\left(\underline{\mathrm{C}}^{\mathrm{Ar}} \mathrm{H}\right), 129.49\left(\underline{\mathrm{C}}^{\mathrm{Ar}} \mathrm{H}\right), 129.03\left(\mathrm{q},{ }^{2} J_{\mathrm{CF}}=\right.$ $\left.30.5 \mathrm{~Hz}, m-\mathrm{C}^{\mathrm{BArF24}}\right), 124.70\left(\mathrm{q},{ }^{1} J_{\mathrm{CF}}=272.8 \mathrm{~Hz}, \underline{\mathrm{CF}}_{3}\right), 124.55(\mathrm{~m}-$ $\left.\underline{\mathrm{C}}^{\mathrm{DiPP}} \mathrm{H}\right), 124.45$ (s, DiPP-NCHCHN), 121.28 (s, DiPP-NCHCHN), $117.58\left(\mathrm{t}, J=4.0 \mathrm{~Hz}, p-\mathrm{C}^{\mathrm{BArF} 24}\right), 71.26\left(\mathrm{C}^{\mathrm{benz}} \mathrm{H}\right), 28.49\left(\mathrm{CH}\left(\mathrm{CH}_{3}\right)_{2}\right)$, $24.55\left(\mathrm{CH}\left(\mathrm{CH}_{3}\right)^{\mathrm{a}}\left(\mathrm{CH}_{3}\right)^{\mathrm{b}}\right), 24.22\left(\mathrm{CH}\left(\mathrm{CH}_{3}\right)^{\mathrm{a}}\left(\mathrm{CH}_{3}\right)^{\mathrm{b}}\right)$.

Preparation of “[(Ad-NHC-Trop $\left.)_{2} \mathrm{Au}\right] \mathrm{BArF}_{24}$ ” (Ad-4). At $0^{\circ} \mathrm{C}$, a solution of Ad-2 $(18.7 \mathrm{mg}, 30.0 \mu \mathrm{mol})$ in DCM $(1 \mathrm{ml})$ was added dropwise to a suspension of $\mathrm{NaBArF}_{24}(31.9 \mathrm{mg}, 36.0 \mu \mathrm{mol})$ in DCM $(1.5 \mathrm{ml})$. The mixture is stirred at $0{ }^{\circ} \mathrm{C}$ for $15 \mathrm{~min}$ before removing the cooling bath and stirring at r.t. over night. Then, the suspension was filtered through a pad of Celite and the filtrate was concentrated on a rotary evaporator before filtering through a pad of silica (glass pipette, $1 / 3$ filled) which was subsequently rinsed with DCM $(3 \times 1 \mathrm{ml})$. The residue was concentrated to approx. $0.2 \mathrm{ml}$ and the product was obtained by the addition of pentane $(3 \mathrm{ml})$ as an oil. After decanting the solution, the product solidified upon drying under vacuum to give a white powder $(20 \mathrm{mg}, 72 \%$ yield with respect to the starting quantity of ligand). Crystals suitable for X-Ray diffraction analysis were obtained by layering a solution of $\mathbf{A d - 3}$ in $\mathrm{CHCl}_{3}$ with pentane. Anal. Calcd. for $\mathrm{C}_{88} \mathrm{H}_{68} \mathrm{AuBF}_{24} \mathrm{~N}_{4}(1845.25 \mathrm{~g} / \mathrm{mol}): \mathrm{C}, 57.28 ; \mathrm{H}, 3.71 ; \mathrm{N}$, $3.04 \%$. Found: C, 57.19; H, 3.60; N, 3.10\%. ${ }^{1} \mathrm{H}$ NMR $(500.13 \mathrm{MHz}$, $\mathrm{CDCl}_{3}$ ): 7.72 (br.s, $\left.4 \mathrm{H}, \quad o-\mathrm{C}^{\mathrm{BArF} 24} H\right), 7.62-7.57(\mathrm{~m}, \quad 2 \mathrm{H}$, $\left.\mathrm{C}^{\text {benz. }} \mathrm{C}^{\text {quart. }} \mathrm{C}^{\mathrm{Ar}} H\right), 7.52\left(\mathrm{~s}, 2 \mathrm{H}, p-\mathrm{C}^{\mathrm{BArF} 24} H\right), 7.43-7.38(\mathrm{~m}, 2 \mathrm{H}$, $\left.\mathrm{C}^{\text {olef. }} \mathrm{C}^{\text {quart. }} \mathrm{C}^{\mathrm{Ar}} H\right), 7.35-7.30\left(\mathrm{~m}, 4 \mathrm{H}, \mathrm{C}^{\mathrm{Ar}} H\right), 7.00\left(\mathrm{~s}, 3 \mathrm{H}, 2 \mathrm{C}^{\text {olef. }} H+\right.$ 2Ad-NCHCHN), $6.83\left(\mathrm{~d},{ }^{3} \mathrm{~J}_{\mathrm{H}, \mathrm{H}}=2.0 \mathrm{~Hz}, 2 \mathrm{H}, \mathrm{Ad}-\mathrm{NCHC} H \mathrm{~N}\right), 6.80(\mathrm{~s}$, $\left.2 \mathrm{H}, \mathrm{C}^{\text {benz. }} H\right), 2.24\left(\mathrm{~d}, J=2.1 \mathrm{~Hz}, 6 \mathrm{H}, \mathrm{C}^{\mathrm{Ad}} H_{2}\right), 2.08\left(\mathrm{~s}, 3 \mathrm{H}, \mathrm{C}^{\mathrm{Ad}} H\right), 1.66$ $\left(\mathrm{d},{ }^{2} J_{\mathrm{HH}}=12.5 \mathrm{~Hz}, 3 \mathrm{H}, \mathrm{C}^{\mathrm{Ad}} H^{\mathrm{a}} \mathrm{H}^{\mathrm{b}}\right), 1.51\left(\mathrm{~d},{ }^{2} J_{\mathrm{HH}}=12.0 \mathrm{~Hz}, 3 \mathrm{H}\right.$, $\left.\mathrm{C}^{\mathrm{Ad}} \mathrm{H}^{\mathrm{a}} \mathrm{H}^{\mathrm{b}}\right) .{ }^{13} \mathrm{C}\left\{{ }^{1} \mathrm{H}\right\}$ DEPTQ NMR $\left(125.76 \mathrm{MHz}, \mathrm{CDCl}_{3}\right): 180.46$ $(\mathrm{NCN}), 161.84\left(\mathrm{q},{ }^{1} J_{\mathrm{CB}}=49.9 \mathrm{~Hz}, \mathrm{~B}-\underline{\mathrm{C}}^{\mathrm{BArF} 24}\right), 135.15\left(\underline{\mathrm{C}}^{\text {quart.trop }}\right)$, $134.95\left(o-\underline{C}^{\text {BArF24 }}\right), 134.44\left(\underline{\mathrm{C}}^{\text {quart.trop }}\right), 131.23\left(\underline{\mathrm{C}}^{\text {olef. }} H\right), 130.49,129.38$, $\left.129.34,129.07+\mathrm{C}^{\text {olef. }} \mathrm{C}^{\text {quart. }} \underline{\mathrm{C}}^{\mathrm{Ar}} \mathrm{H}\right),\left(\mathrm{C}^{\text {benz. }} \mathrm{C}^{\text {quart. }} \underline{C}^{\mathrm{Ar}} \mathrm{H}\right),\left(\underline{\mathrm{C}}^{\mathrm{Ar}} \mathrm{H}\right),\left(\underline{\mathrm{C}}^{\mathrm{Ar}} \mathrm{H}\right)$, $129.87\left(\mathrm{~m}, m-\mathrm{C}^{\mathrm{BArF24}}\right), 124.69\left(\mathrm{q},{ }^{1} J_{\mathrm{CF}}=272.7 \mathrm{~Hz}, \underline{\mathrm{CF}}_{3}\right), 120.58(\mathrm{~s}$, Ad-NCHCHN), 117.59 (br. s, $p$-C ${ }^{\text {BArF24 }}$ ), 116.83 (s, Ad-NCHCHN), $71.34\left(\underline{C}^{\text {benz. }} \mathrm{H}\right), 59.37\left(\underline{C}^{\text {quart. }}-\mathrm{N}\right), 44.66\left(\mathrm{~N}-\underline{C}^{\mathrm{Ad}} \mathrm{H}_{2}\right), 35.58\left(\underline{\mathrm{C}}^{\mathrm{Ad}} \mathrm{H}_{2}\right)$, $29.83\left(\underline{\mathrm{C}}^{\mathrm{Ad}} \mathrm{H}\right)$.

Preparation of "I(Trop-NHC-Trop $\left.)_{2} \mathrm{Au}\right] \mathrm{BArF} \mathrm{B}_{24}$ " (Trop-4). A mixture of $\mathrm{NaBArF}_{24}(42.6 \mathrm{mg}, 48.0 \mu \mathrm{mol})$ and Trop-2 $(27.2 \mathrm{mg}$, $40 \mu \mathrm{mol}$ ) was dried under vacuum for approximately $10 \mathrm{~min}$, dissolved in $2 \mathrm{ml}$ of dry DCM and stirred at room temperature over night. A black precipitate formed and the suspension was filtered through a pad of Celite (glass pipette, 1/3 filled) which was subsequently rinsed with DCM $(3 \times 1 \mathrm{ml})$. The filtrate was concentrated on a rotary evaporator to approx. $0.3 \mathrm{ml}$, filtered through a pad of silica (glass pipette, $1 / 2$ filled) which was subsequently rinsed with DCM (3 $\times 1 \mathrm{ml}$ ). After evaporating the filtrate to dryness, the residue was triturated with pentane $(3 \times 2 \mathrm{ml})$ and dried in vacuo to give the product as a white powder $(34 \mathrm{mg}, 87 \%$ yield with respect to the starting quantity of ligand). Anal. Calcd. for $\mathrm{C}_{98} \mathrm{H}_{60} \mathrm{AuBF}_{24} \mathrm{~N}_{4}(1957.29$ g/mol): C, 60.14; H, 3.09; N, 2.86\%. Found: C, 60.04; H, 3.01; N, $3.02 \%$. ${ }^{1} \mathrm{H}$ NMR $\left(500.13 \mathrm{MHz}, \mathrm{CDCl}_{3}\right): 7.74$ (br.s, $8 \mathrm{H}, o-\mathrm{C}^{\mathrm{BArF} 24} H$ ), $7.58-7.48\left(\mathrm{~m}, 20 \mathrm{H}, 16 \mathrm{C}^{\mathrm{Ar}} H+4 p-\mathrm{C}^{\mathrm{BArF} 24} H\right), 7.27(\mathrm{dt}, J=11.0 \mathrm{~Hz}, J$ $=1.5 \mathrm{~Hz}, 8 \mathrm{H}, \mathrm{C}^{\mathrm{Ar}} H$ ), 7.00 (br.s, $8 \mathrm{H}, \mathrm{C}^{\text {benz. }} \mathrm{C}^{\text {quart. }} \mathrm{C}^{\mathrm{Ar}} H$ ), 6.98 (br.s, $8 \mathrm{H}$, $\left.\mathrm{C}^{\text {olef. }} H\right), 6.05\left(\mathrm{~s}, 4 \mathrm{H}, \mathrm{C}^{\text {imi }} H\right), 5.68\left(\mathrm{~s}, 4 \mathrm{H}, \mathrm{C}^{\text {benz. }} H\right) .{ }^{13} \mathrm{C}\left\{{ }^{1} \mathrm{H}\right\}$ DEPTQ NMR (125.76 MHz, $\left.\mathrm{CDCl}_{3}\right): 184.30(\mathrm{NCN}), 161.88\left(\mathrm{q},{ }^{1} J_{\mathrm{CB}}=49.8\right.$ $\left.\mathrm{Hz}, \quad \mathrm{B}-\mathrm{C}^{\mathrm{BArF24}}\right), \quad 135.22 \quad\left(\mathrm{C}^{\text {quart.trop }}\right), \quad 134.96\left(o-\mathrm{C}^{\mathrm{BArF} 24}\right), 134.73$ $\left(\underline{C}^{\text {quart.trop }}\right), 131.13\left(\mathrm{C}^{\text {benz. }} \mathrm{C}^{\text {quart }}{ }^{\mathrm{Ar}} \mathrm{H}\right), 130.89\left(\mathrm{C}^{\text {olef. }} H\right), 129.09\left(\underline{C}^{\mathrm{Ar}} \mathrm{H}\right)$, $129.93\left(\underline{\mathrm{C}}^{\mathrm{Ar}} \mathrm{H}\right), 129.49\left(\underline{\mathrm{C}}^{\mathrm{Ar}} \mathrm{H}\right), \sim 129.0\left(\mathrm{~m}-\mathrm{C}^{\mathrm{BArF}}{ }^{24}\right.$, parts of the quartett are overlayered and not clearly visible), $124.71\left(\mathrm{q},{ }^{1} J_{\mathrm{CF}}=272.8 \mathrm{~Hz}\right.$, $\left.\underline{\mathrm{CF}}_{3}\right), 118.81$ (s, $\left.\underline{\mathrm{C}}^{\mathrm{imi}} \mathrm{H}\right), 117.59$ (bs, $\left.p-\mathrm{C}^{\mathrm{BArF24}}\right), 69.20\left(\underline{\mathrm{C}}^{\text {benz. }} \mathrm{H}\right)$.

General procedure for the hydration of diphenylacetylene: under air, $2 \mathrm{ml}$ of a mixture of 1,4-dioxane and water $(2: 1)$ were added to a 3-ml glass vial charged with the catalyst R-3 $(2.5-5 \mathrm{~mol} \%)$ and diphenylacetylene $(89.1 \mathrm{mg}, 500 \mu \mathrm{mol})$. The vessel was sealed and heated at $80{ }^{\circ} \mathrm{C}$ for $24 \mathrm{~h}$. After cooling to room temperature, the mixture was diluted with pentane and a sample of the organic layer was analyzed via GC.

\section{ASSOCIATED CONTENT}

\section{Supporting Information}

Contains general information on synthetic procedures, NMR spectra and X-ray diffraction data. This material is available free of charge via the Internet at http://pubs.acs.org.

\section{X-ray Crystallography}

CCDC 1029001 (Me-2), 1028999 (DiPP-2), 1028996 (Ad-2), 1028994 (Trop-2), 1029002 (Me-3), 1029000 (DiPP-3), 1028997 (Ad-3), 1028995 (Trop-3), 1029003 (Me-4), 1028998 (Ad-4) contain the supplementary crystallographic data for this paper. These data can be obtained free of charge from the cambridge crystallographic data center via:

http://www.ccdc.cam.ac.uk/data_request/cif.

\section{AUTHOR INFORMATION}

\section{Corresponding Author}

*E-mail: snolan@st-andrews.ac.uk

\section{ACKNOWLEDGMENT}

The ERC (Advanced Investigator Award-FUNCAT), Syngenta and the EPSRC are gratefully thanked for support of this work. Umicore AG is thanked for generous donations of auric acid. S.P.N. is a Royal Society Wolfson Research Merit Award holder. Mr. Enrico Marelli is thanked for helpful discussions regarding the synthesis of the imidazolium salts. 


\section{REFERENCES}

(1) Selected reviews on synthesis and properties of NHC metal complexes: (a) de Frémont, P.; Marion, N.; Nolan, S. P. Coord. Chem. Rev. 2009, 253, 862; (b) Lin, J. C. Y.; Huang, R. T. W.; Lee, C. S.; Bhattacharyya, A.; Hwang, W. S.; Lin, I. J. B. Chem. Rev. 2009, 109, 3561; (c) Poyatos, M.; Mata, J. A.; Peris, E. Chem. Rev., 2009, 3677; (d) Jahnke, M. C.; Hahn, F. E. Angew. Chem. Int. Ed. 2008, 47, 3122. (2) (a) Enders, D.; Niemeier, O.; Henseler, A. Chem. Rev. 2007, 107, 5606; (b) Marion, N.; Díez-González, S.; Nolan, S. P. Angew. Chem., Int. Ed. 2007, 46, 2988.

(3) Edited Books on modern NHC chemistry and applications: (a) NHeterocyclic Carbenes; Nolan, S. P., Ed.; Wiley-VCH, Weinheim, 2014; (b) N-Heterocyclic Carbenes in Transition Metal Catalysis; Cazin, C. S. J., Ed.; Springer: Berlin, Germany, 2011. (c) NHeterocyclic Carbenes in Transition Metal Catalysis: Top. Organomet. Chem.; Glorius, F., Ed.; Springer-Verlag, Berlin/Heidelberg, 2007, Vol. 28.

(4) For reviews on cross-coupling reactions, see: (a) Fortman, G. C.; Nolan, S.P. Chem. Soc. Rev. 2011, 40, 5151; (b) Marion, N.; Nolan, S. P. Acc. Chem. Res. 2008, 41, 1440-1449; (c) Würtz, S.; Glorius, F. Acc. Chem. Res. 2008, 41, 1523-1533; (d) Kantchev, E. A. B.; O'Brien, C. J.; Organ, M. G., Angew. Chem., Int. Ed. 2007, 46, 27682813; (e) For a reviews on olefin metathesis, see: Vougioukalakis, G. C.; Grubbs, R. H. Chem. Rev. 2010, 110, 1746.

(5) General reviews on NHC-based transition-metal catalysis: (a) Díez-González, S.; Marion, N.; Nolan, S. P. Chem. Rev. 2009, 109, 3612; (b) Herrmann, W. A. Angew. Chem., Int. Ed. 2002, 41, 1290.

(6) For a fantastic overview on the application of NHCs in modern chemistry: Hopkinson, M. N; Richter, C.; Schedler, M.; Glorius, F. Nature 2014, 510, 485

(7) (a) Hashmi, A. S. K.; Lauterbach, T.; Nösel, P.; Højer Vilhelmsen, M.; Rudolph, M.; Rominger, F. Chem. Eur. J. 2013, 19, 1058; (b) Wurm, T.; Asiri, A. M.; Hashmi, A. S. K. NHC-Au(I) Complexes: Synthesis, Activation, and Application. In N-Heterocyclic Carbenes; Nolan, S. P., Ed.; Wiley-VCH, Weinheim, 2014, pp 243-267; (c) Hashmi, A. S. K.; Rudolph, M. Chem. Commun. 2011, 47, 6536; (d) Nolan, S. P. Acc. Chem. Res. 2011, 44, 91; (e) Gorin, D. J.; Sherry, B D.; Toste, F. D. Chem. Rev. 2008, 108, 3351; (f); Jiménez-Núnez, E.; Echavarren, A. M. Chem. Rev. 2008, 108, 3239; (g) Hashmi, A. S. K. Chem. Rev. 2007, 107, 3180; (h) Fürstner, A.; Davis, P. W. Angew. Chem., Int. Ed. 2007, 46, 3410; (i) Arcadi, A. Chem. Rev. 2008, 108, 3266.

(8) (a) Dröge, T.; Glorius, F. Angew. Chem., Int. Ed. 2010, 49, 6940; (b) Clavier, H.; Nolan, S. P. Chem. Commun. 2010, 46, 841; (c) DíezGonzález, S.; Nolan, S. P. Coord. Chem. Rev. 2007, 251, 874; (d) Cavallo, L.; Correa, A.; Costabile, C.; Jacobsen, H. J. Organomet. Chem. 2005, 690, 5407.

(9) NHC systems: (a) de Frémont, P.; Marion, N.; Nolan, S. P. J. Organomet. Chem. 2009, 694, 551; (b) de Frémont, P.; Stevens, E. D.; Fructos, M. R.; Díaz-Requejo, M. M.; Pérez, P. J.; Nolan, S. P. Chem. Commun. 2006, 2045; Phosphine systems: (c) Khin, C.; Hashmi, A. S. K.; Rominger, F. Eur. J. Inorg. Chem. 2010, 1063; (d) HerreroGómez, E.; Nieto-Oberhuber, C.; López, S.; Benet-Buchholz, J.; Echavarren, A. M. Angew. Chem. Int. Ed. 2006, 45, 5455; (e) NietoOberhuber, C.; López, S.; Muñoz, M. P.; Buñuel, E.; Nevado, C.; Cárdenas, D. J.; Echavarren, A. M.; Angew. Chem., Int. Ed. 2004, 43, 2402.

(10) For a triazole-based system, see: (a) H. Duan, S. Sengupta, J. L. Petersen, N. G. Akhmedov, X. Shi, J. Am. Chem. Soc. 2009, 131 12100; for pyridine-based systems, see ref. $9 \mathrm{a}$

(11) (a)Tsui, E. Y.; Müller, P.; Sadighi, J. P. Angew. Chem., Int. Ed. 2008, 47, 8937 .

(12) (a) Ricard, L.; Gagosz, F. Organometallics 2007, 26, 4704 (b); Mézailles, N.; Ricard, L.; Gagosz, F. Org. Lett. 2005, 7, 4133.

(13) For a silver-free synthetic protocol of these complexes, see: Gaillard, S.; Slawin, A. M. Z.; Nolan, S. P. Chem. Commun. 2010, 46, 2742.

(14) Brown, T. J.; Dickens, M. G.; Widenhoefer, R. A. J. Am. Chem. Soc. 2009, 131, 6350 .
(15) Selected works on Tropp ligands: (a) Böhler, C.; Avarvari, N.; Schönberg, H.; Wörle, M.; Rüegger, H.; Grützmacher, H. Helv. Chim. Acta 2001, 84, 3127; (b) Schönberg, H.; Boulmaâz, S.; Wörle, M.; Liesum, L.; Schweiger, A.; Grützmacher, H. Angew. Chem., Int. Ed. 1998, 37, 1423; (c) Thomaier, J.; Boulmaâz, S.; Schönberg, H.; Rüegger, H.; Currao, A.; Grützmacher, H.; Hillebrecht, H.; Pritzkow, H. New. J. Chem. 1998, 947.

(16) Selected works on nitrogen-based Trop-ligands: (a) Rosenthal, A. J.; Vogt, M.; de Bruin, B.; Grützmacher, H. Eur. J. Inorg. Chem. 2013, 5831; (b) Donati, N.; Stein, D.; Büttner, T.; Schönberg, H.; Harmer, J.; Anadaram, S.; Grützmacher, H. Eur. J. Inorg. Chem. 2008, 4691; (c) Königsmann, M.; Donati, N.; Stein, D.; Schönberg, H.; Harmer, J.; Sreekanth, A.; Grützmacher, H. Angew. Chem., Int Ed. 2007, 46, 3567.

(17) Fischbach, U.; Rüegger, H.; Grützmacher, H. Eur. J. Inorg. Chem. 2007, 2654.

(18) Böhler, C.; Stein, D.; Donati, N.; Grützmacher, H., New. J. Chem. 2002, 26, 1291.

(19) Carried out in accordance with a procedure reported in: Vogt, M. Dissertation, ETH Zürich, Zürich, 2010.

(20) Collado, A.; Gómez-Suárez, A.; Martin, A. R.; Slawin, A. M. Z.; Nolan, S. P. Chem. Commun. 2013, 49, 5541.

(21) Wang, H. M. J.; Lin I. J. B. Organometallics 1998, 17, 972.

(22) López-Gómez, M. J.; Marin, D.; Bertrand, G. Chem. Commun. 2013, 49, 4483 .

(23) de Frémont, P.; Scott, N. M.; Stevens, E. D.; Nolan, S. P., Organometallics 2005, 24, 2411-2418.

(24) This software is available free of charge at http://www.molnac.unisa.it/OMtools.php

(25) (a) Collado, A.; Balogh, J.; Meiries, S.; Slawin, A. M. Z.; Falivene, L.; Cavallo, L.; Nolan, S. P. Organometallics 2013, 32, 3249; (b) Cavallo, L.; Cazin, C. S. J.; Nolan, S. P. Chem. Eur. J. 2012, 18 , 4517; (c) Wu, L.; Drinkel, E.; Gaggia, F.; Capolicchio, S.; Linden, A.; Falivene, L.; Cavallo, L.; Dorta, R. Chem. Eur. J. 2011, 17, 12886; (d) Poater, A.; Ragone, F.; Mariz, R.; Dorta, R.; Cavallo, L. Chem. Eur. J. 2010, 16, 14348; (e) Ragone, F.; Poater, A.; Cavallo, L. J. Am. Chem. Soc. 2010, 132, 4249.

(26) (a) Hillier, A. C.; Sommer, W. J.; Yong, B. S.; Petersen, J. L.; Cavallo, L.; Nolan, S. P., Organometallics 2003, 22; for a comprehensive review on steric properties in organometallic chemistry and the buried volume model, see ref. $8 \mathrm{~b}$.

(27) (a) Chartoire, A.; Frogneux, X.; Nolan, S. P. Adv. Synth. Catal. 2012, 354, 1897; (b) Gómez-Suárez, A.; Ramón, R. S.; Songis, O.; Slawin, A. M. Z.; Cazin, C. S. J.; Nolan, S. P. Organometallics 2011, 30, 5463; (c) Laskowski, C. A.; Miller, A. J. M.; Hillhouse, G. L.; Cundari, T. R. J. Am. Chem. Soc. 2010, 133, 771; Berthon-Gelloz, G.; Siegler, M. A.; Spek, A. L.; Tinant, B.; Reek, J. N. H.; Marko, I. E., Dalton Trans. 2010, 39, 1444.

(28) Brookhart, M.; Grant, B.; Volpe, A. F. Organometallics 1992, 11,3920 .

(29) Due to a disorder in the orientation of the $\mathrm{CF}_{3}$ group at $\mathrm{S} 2$ in Trop-3, the obtained data for this complex have limited value. Nevertheless, it is clearly visible that the twisting between the NHC- and $\mathrm{NTf}_{2}$-units is enforced by the Trop-substituent which reaches far into the space next to the metal center.

(30) Gaillard, S.; Nun, P.; Slawin, A. M. Z.; Nolan, S. P. Organometallics 2010, 29, 5402.

(31) Gaillard, S.; Bosson, J.; Ramón, R. S.; Nun, P.; Slawin, A. M. Z.; Nolan, S. P. Chem. Eur. J. 2010, 16, 13729.

(32) Weber, S. G.; Zahner, D.; Rominger, F.; Straub, B. F. Chem. Commun. 2012, 48, 11325.

(33) Weber, S. G.; Zahner, D.; Rominger, F.; Straub, B. F. Chem. Cat. Chem. 2013, 5, 2330.

(34) Marion, N.; Ramón, R. S.; Nolan, S. P. J. Am. Chem. Soc. 2009, $131,448$. 